\title{
Electrocatalytic Activities towards the Electrochemical Oxidation of Formic Acid and Oxygen Reduction Reactions over Bimetallic, Trimetallic and Core-Shell-Structured Pd-Based Materials
}

\author{
Takao Gunji * and Futoshi Matsumoto *(1) \\ Department of Material and Life Chemistry, Kanagawa University, 3-27-1, Rokkakubashi, Kanagawa-ku, \\ Yokohama, Kanagawa 221-8686, Japan \\ * Correspondence: tgunji@kanagawa-u.ac.jp (T.G.); fmatsumoto@kanagawa-u.ac.jp (F.M.)
}

Received: 11 January 2019; Accepted: 27 February 2019; Published: 7 March 2019

\begin{abstract}
The structural design of nanosized electrocatalysts is extremely important for cathodic oxygen reduction reactions (ORR) and anodic oxidation reactions in small organic compounds in direct fuel cells. While Pt is still the most commonly used electrode material for ORR, the Pd electrocatalyst is a promising alternative to $\mathrm{Pt}$, because it exhibits much higher electrocatalytic activity towards formic acid electrooxidation, and the electrocatalytic activity of ORR on the Pd electrode is the higher than that of all other precious metals, except for Pt. In addition, the mass activity of Pt in a core-shell structure for ORR can be improved significantly by using Pd and Pd-based materials as core materials. Herein, we review various nanoscale Pd-based bimetallic, trimetallic and core-shell electrocatalysts for formic acid oxidation and ORR of polymer electrolyte fuel cells (PEFCs). This review paper is separated into two major topics: the electrocatalytic activity towards formic acid oxidation over various Pd-based electrocatalysts, and the activity of ORR on Pd-based materials and Pd core-Pt shell structures.
\end{abstract}

Keywords: electrocatalyst; oxidation of formic acid; oxygen reduction reaction; Pd-based materials; bimetallic compound; core-shell structure

\section{Introduction}

Owing to their high electrocatalytic activity, Pt-based electrocatalysts have been extensively investigated as electrode materials for oxygen reduction reaction (ORR) and the electrooxidation of small organic compounds in polymer electrolyte fuel cells (PEFCs), which are potential alternatives to fossil fuel-based devices [1]. However, Pt-based electrocatalysts suffer from several limitations. Since $\mathrm{Pt}$ is costly, rarely available and has high overpotential for ORR and the oxidation of small organic molecules, it is imperative to develop an electrocatalyst with little or no Pt for the commercialization of both PEFCs and direct methanol fuel cells (DMFCs).

In DMFCs, methanol in aqueous solution has an ideal energy density $\left(4900 \mathrm{Wh} \mathrm{L}^{-1}\right)$, however, the open circuit potential (OCP) is lower than that in PEFCs, due to the higher standard oxidation potential of methanol and the higher overpotential for electrocatalytic methanol oxidation. In addition, formic acid as a fuel shows a smaller crossover than methanol when Nafion ${ }^{\circledR}$ is used as an ionomer, indicating that formic acid allows the use of electrolytes with high concentrations. Moreover, the standard oxidation potential for formic acid is approximately $-0.25 \mathrm{~V}$ versus the reversible hydrogen electrode (RHE) [2], which is lower than that of the oxidation of methanol and $\mathrm{H}_{2}$. The theoretical electromotive force (emf) and OCP of direct formic acid fuel cells ( $1.48 \mathrm{~V}$ versus RHE) is higher than that of PEFCs (1.23 V versus RHE) [2-4]. Therefore, direct formic acid fuel cells are highly 
promising, and it is of great significance to develop an electrocatalyst with high activity towards the electrooxidation of formic acid.

Pt shows lower catalytic activity towards ORR in the presence of methanol (mixed in the electrolyte by methanol crossover) in acidic media. Therefore, various efforts have been made to develop electrocatalysts with little or no Pt for the oxidation of small organic compounds and ORR in fuel cells $[5,6]$. Pd-based electrocatalysts are potential alternatives to Pt for ORR under both acidic and alkaline conditions because Pd has similar physicochemical characteristics (e.g., the crystal structure and being a group 10 element in the periodic table) to those of $\mathrm{Pt}$. With the exception of $\mathrm{Pt}, \mathrm{Pd}$ exhibits the highest electrocatalytic activity (among pure metals) towards hydrogen evolution reactions and ORR. In addition, the ORR kinetics of Pd-based electrocatalysts are not significantly affected by methanol because of their high tolerance to methanol under acidic conditions [7-9]. While Pd is currently more expensive than Pt (Pd: 1232.5 USD/ozt and Pt: 796.66 USD/ozt on 5th December 2018), the prices of precious metals fluctuate by nature. Historically, $\mathrm{Pt}$ has been more expensive than $\mathrm{Pd}$, therefore, we still believe that exploring Pt-free catalysts is valuable. In addition, to prepare metal nanoparticles, metal sources should be used as precursors. Pt precursors are still more expensive than their Pd analogues at most chemical vendors, such as Sigma-Aldrich. For example, the prices of Pd(II) acetylacetonate (99\%) and $\mathrm{Pt}(\mathrm{II})$ acetylacetonate (99.98\%) are currently 85 and $170 \mathrm{USD} / \mathrm{g}$, respectively, at Sigma-Aldrich.

In the case of Pd electrocatalysts for ORR, under acidic conditions, the electrocatalytic activity of ORR over Pd appear to be lower than that of Pt because of a non-ideal d-band center value, which produces strongly absorbed oxygen during the initial ORR process (as mentioned in Section 3.1). Therefore, to realize highly active Pd-based electrocatalysts for ORR, it is significant to control their crystal structures and electronic conditions. On the other hand, in order to prepare Pt-based electrocatalysts with lower d-band centers and hence higher ORR activity, three-dimensional transition metals such as $\mathrm{Fe}, \mathrm{Co}, \mathrm{Ni}$ and $\mathrm{Cu}$ are used as alloying materials to modify the electronic state and crystal structure of $\mathrm{Pt}$ [10-12]. This suggests that by modifying the electronic state and crystal structure of $\mathrm{Pd}$ with transition metal electrocatalysts, with activity comparable to that of $\mathrm{Pt}$, a possibility that highly active Pd-based electrocatalysts may be achieved.

So far, there are several reviews on the activity of Pd- and Pt-based materials for PEFC catalysts [5,6,13-20]. Antolini has reported on the ORR activity of alloys and so-called ordered intermetallic compounds, which are atomically ordered stoichiometrically, unlike the random structure of alloy compounds. Ordered intermetallic compounds can be expected to realize a higher electrocatalytic activity when compared with random alloy compounds due to their long-term chemical ordering, resulting in intermetallic compounds that can form homogeneously active sites. In fact, most parts of ordered intermetallic compounds, such as $\mathrm{Pt}_{x} \mathrm{Co}_{y}, \mathrm{Pt}_{x} \mathrm{Fe}_{y}, \mathrm{Pt}_{x} \mathrm{Ni}_{y}$ and $\mathrm{Pd}_{x} \mathrm{Fe}_{y}$, can exhibit a higher electrocatalytic activity towards ORR, compared with their random alloy compounds [14]. Erikson has reviewed recent progress on the electrocatalytic activity towards ORR over Pd-based materials. Size, substrate, morphology and the crystal structure effect have been reviewed adequately [15].

In this review, we focus on the electrochemical oxidation of small organic compounds over Ptand Pd-based catalysts and compare the activities of Pd and various Pd-based electrocatalysts in terms of the electrooxidation of formic acid in Section 2. In Section 3, the ORR activities of Pd and Pd-based catalysts under both alkaline and acidic conditions are summarized. High-performance Pt-decorated $\mathrm{Pd}$ and Pd bimetallic alloy electrocatalysts for ORR are also discussed in this section. Effective alloying with intermetallic compounds and a core-shell structure can reduce $\mathrm{Pd}$ and Pt loading and increase electrocatalytic activity. 


\section{Electrocatalysts for Direct Fuel Cells}

\subsection{Electrocatalytic Activity for the Oxidation of Small Organic Compounds}

Direct fuel cells, which use small organic compounds as fuel, have gained significant attention as next-generation energy conversion systems, owing to their high energy density and use of low-toxicity fuels. The electrochemical oxidation of small organic compounds can be catalyzed by $\mathrm{Pt}, \mathrm{Pd}$ and their bimetallic compounds. Pt is widely used to catalyze the electrooxidation of methanol and ethanol in acidic media, owing to its strong adsorption and dissociation of methanol and ethanol [13,21]. Cai et al., Bianchini et al., Ma et al. and Xie et al. have reviewed the catalytic activities of Pt- and Pd-based catalysts for the electrooxidation of ethanol in alkaline media and the electrooxidation of formic acid and the corresponding reaction mechanisms $[13,16,17,19]$. The oxidation reaction proceeds via multiple pathways with direct and indirect processes. However, the methanol and ethanol oxidation reactions are kinetically limited because of the slow dissociative adsorption of methanol and ethanol and the formation of a $\mathrm{CO}_{\mathrm{ad}}$ species on the surface of $\mathrm{Pt}$ [22]. Therefore, in the case of a Pt electrocatalyst, a high overpotential is required for the oxidation of ethanol and methanol. The onset potential for methanol oxidation over $\mathrm{Pt}$ is approximately $0.5 \mathrm{~V}$ versus RHE [21,23], because of which the effective voltage for DMFCs is significantly lower than that of hydrogen fuel cells (FCs). Kodiyath and coworkers showed that the electrocatalytic activity of intermetallic $\mathrm{Pt}_{3} \mathrm{Ta}$ towards ethanol oxidation is superior to that of pure $\mathrm{Pt}$. The reaction mechanism of ethanol oxidation over $\mathrm{Pt}_{3} \mathrm{Ta}$ has been elucidated using potential-dependent in situ infrared reflection-absorption spectroscopy (IRRAS). It has been reported that ordered intermetallic $\mathrm{Pt}_{3} \mathrm{Ta}$ nanocrystals can promote not only $\mathrm{C}-\mathrm{C}$ cleavage, but also the conversion of ethanol to $\mathrm{CO}_{2}$ [24].

Since formic acid can be easily oxidized to $\mathrm{CO}_{2}$ at low overpotentials, the oxidation of formic acid over Pt has also been investigated extensively. The electrooxidation of formic acid can proceed via two reaction pathways: The dehydrogenation and dehydration pathways. IRRAS studies have revealed that carbon monoxide is formed as an intermediate during the electrodecomposition of formic acid (because of its dehydration) [25-27]. The direct two-electron pathway for the conversion of formic acid to $\mathrm{CO}_{2}$ proceeds as a minor pathway on the surface of Pt electrocatalysts $[27,28]$. Wang and coworkers proposed a reaction pathway for the electrochemical oxidation of formic acid over $\mathrm{Pt}$ (111), based on Vanderbilt-type ultra-soft pseudopotential calculations in both the gas and liquid phases $[29,30]$.

\subsection{Electrooxidation of Formic Acid on Pt-Based Electrocatalysts}

Formic acid has gained immense attention as a fuel for direct fuel cells because the current density for the electrooxidation of formic acid over Pd and Pd-based materials is much higher than that of Pt-based electrocatalysts [6,31], because of their catalytically different pathways. The direct pathway for the oxidation of formic acid produces $\mathrm{CO}_{2}\left(\mathrm{HCOOH} \rightarrow \mathrm{CO}_{2}+2 \mathrm{H}^{+}+2 \mathrm{e}^{-}\right)$. In the $\mathrm{CO}$ pathway $\left(\mathrm{HCOOH} \rightarrow \mathrm{CO}+\mathrm{H}_{2} \mathrm{O}\right)$, the dehydration of formic acid produces $\mathrm{CO}$ as an intermediate, which then oxidizes to $\mathrm{CO}_{2}\left(\mathrm{CO}+\mathrm{H}_{2} \mathrm{O} \rightarrow \mathrm{CO}_{2}+2 \mathrm{H}^{+}+2 \mathrm{e}^{-}\right)$.

It is well-known that $\mathrm{Pd}$ and $\mathrm{Pt}$ are the main electrocatalysts for the oxidation of formic acid. The electrooxidation of formic acid over Pt proceeds mainly via an indirect pathway, which involves the formation of $\mathrm{CO}$ via the dehydration reaction of formic acid.

$$
\begin{gathered}
\mathrm{Pt}+\mathrm{HCOOH} \rightarrow \mathrm{Pt}-\mathrm{CO}+\mathrm{H}_{2} \mathrm{O} \\
\mathrm{Pt}+\mathrm{H}_{2} \mathrm{O} \rightarrow \mathrm{Pt}-\mathrm{OH}+\mathrm{H}^{+}+\mathrm{e}^{-} \\
\mathrm{Pt}-\mathrm{CO}+\mathrm{Pt}-\mathrm{OH} \rightarrow 2 \mathrm{Pt}+\mathrm{CO}_{2}+\mathrm{H}^{+}+\mathrm{e}^{-}
\end{gathered}
$$

The CO pathway proceeds preferentially when $\mathrm{Pt}$ is used as the electrocatalyst and the intermediate $\mathrm{CO}$ formed by the CO pathway is adsorbed on the Pt surface. The water activation reaction (2), which is necessary to remove $\mathrm{CO}$ from the surface of $\mathrm{Pt}$, is difficult to proceed and hence 
reduces the electrocatalytic activity of Pt. An ideal formic acid oxidation electrocatalyst should function via the dehydrogenation pathway (direct pathway) while avoiding its poisoning. Till date, several efforts have been made to improve the direct pathway electrocatalytic oxidation of formic acid over Pt-based compounds. For example, $\mathrm{CO}_{2}$ can be formed via the direct pathway by adding atomic Au to the Pt lattice [32]. However, it is difficult to completely avoid the indirect pathway.

Abruña and coworkers have shown that ordered intermetallic PtBi and PtPb, which have a NiAs-type structure, exhibit electrocatalytic formic acid oxidation superior to that shown by $\mathrm{Pt}-\mathrm{Ru}$, $\mathrm{Pd}$ and $\mathrm{Pt}[33,34]$. This can be attributed to the $\mathrm{CO}$ tolerance of intermetallic $\mathrm{PtPb}$ [35]. Moreover, $\mathrm{CO}$ is not formed on the surface of intermetallic $\mathrm{PtPb}$ during the electrooxidation of formic acid and methanol. This indicates that intermetallic PtPb electrooxidizes formic acid and methanol via the direct pathway, in which $\mathrm{CO}$ is not formed [36]. These results indicate that the electrooxidation of formic acid over $\mathrm{Pt}$ and intermetallic $\mathrm{PtPb}$ catalysts proceeds via different reaction mechanisms (i.e., the direct pathway mainly proceeds on the intermetallic surface). In addition, ordered intermetallic $\mathrm{PtPb}$ and PtBi show enhanced electrocatalytic activity towards the oxidation of small organic compounds in alkaline media, and $\mathrm{Pb}$ and $\mathrm{Bi}$ in $\mathrm{PtPb}$ and $\mathrm{PtBi}$ can contribute to the electrooxidation of $\mathrm{CO}$ by forming Bi- $(\mathrm{OH})_{\text {ad }}$ [37].

\subsection{Electrooxidation of Formic Acid on Pd Electrocatalysts}

Since the physicochemical characteristics of $\mathrm{Pd}$ (such as the electronic properties and crystal structure) are similar to those of $\mathrm{Pt}$, the electrooxidation of formic acid follows the same pathway on the surface of both Pd and Pt. However, Pd and Pd-based electrocatalysts show significantly higher catalytic activity towards the electrooxidation of formic acid than Pt electrocatalysts. This is because the electrooxidation of formic acid over Pd proceeds mainly via the direct pathway, with the CO pathway acting as the minor reaction [38,39]. The intermediate $\mathrm{CO}$ produced upon the dehydration of formic acid reduces the electrocatalytic activity for formic acid oxidation due to $\mathrm{CO}$ poisoning of the Pt and Pd surfaces. CO formation by dehydration of formic acid proceeded via the carboxyl pathway (i.e., $\mathrm{COOH}^{*}$ ). Mavrikakis et al., calculated free-energy diagrams of formic acid oxidation on Pt and Pd electrocatalysts, including the carboxyl pathway, formate pathway (i.e., $\mathrm{HCOO}^{*}$ ) and indirect carboxyl-mediated mechanism [40]. According to their calculations, the reaction mechanisms via formate and carboxyl have very similar onset potentials to Pd (111), in agreement with other reported results [41]. On the other hand, the free-energy on $\mathrm{Pt}$ (111) is significantly higher for the formate pathway than the carboxyl pathway. CO poisoning on the Pd surface is less than that on the $\mathrm{Pt}$ surface because the $\mathrm{HCOO}^{*}$ pathway can contribute to the overall activity. In addition, Melchionna has reported on Pd-based core-shell catalysts, which underline the possibility of constructing reversible catalysts for $\mathrm{CO}_{2}$ reduction/HCOOH oxidation [42]. Therefore, $\mathrm{Pd}$ is a promising catalyst for the oxidation of formic acid. However, as discussed previously, a small amount of formic acid is still oxidized via the indirect pathway [43].

Recently, Cai and coworkers proposed a novel reaction mechanism for the electrooxidation of formic acid over Pd that is different from the pathways discussed above (direct and CO pathways). They proposed (on the basis of high-sensitivity in situ surface-enhanced IR spectroscopy results) that $\mathrm{CO}$ is formed by the electrochemical reduction of $\mathrm{CO}_{2}$, rather than the direct dehydration of formic acid on the surface of $\mathrm{Pd}$ at potentials where adsorbed $\mathrm{H}$ species exist (Figure 1) [43-45]. The formation of CO inactivates Pd catalysts, therefore, it is important to develop Pd-based electrocatalysts with a high $\mathrm{CO}$ tolerance. 


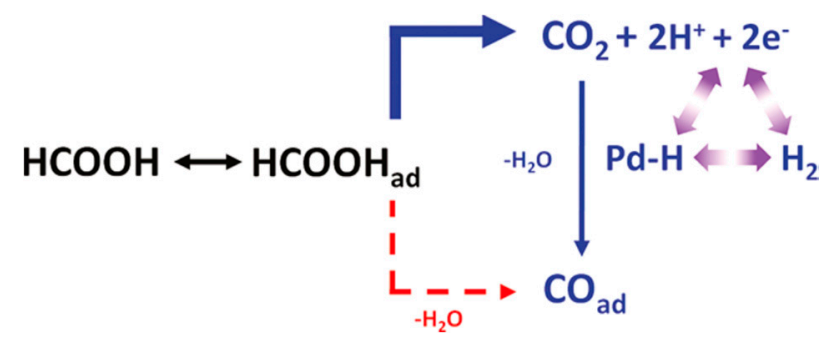

Figure 1. The reaction pathway for the electrooxidation of formic acid over Pd. Reproduced with permission [46]. Copyright 2011, American Chemical Society.

2.4. Effect of Electronic State, Morphology and Structure on the Catalytic Activity of Pd towards Formic Acid Oxidation

Since Pd exhibits the highest electrocatalytic activity (among metals) towards the electrooxidation of formic acid, various efforts have been made to develop Pd-based compounds (Table 1). Co [47], $\mathrm{Ni}[48,49], \mathrm{Cu}[49,50], \mathrm{Pb}[31]$ and $\mathrm{HoO}_{x}$ [51] have been widely used to modify $\mathrm{Pd}$ in order to improve its electrocatalytic activity towards formic acid oxidation (Table 1). Pd-based bi- and tri-metallic compounds show higher electrocatalytic activity towards formic acid oxidation than pure Pd. The electrocatalytic activity (towards formic acid oxidation) of $\mathrm{Pd}$ increases with a decrease in $\mathrm{CO}$ oxidation potential. For example, the dealloying of ordered intermetallic $\mathrm{Pd}_{3} \mathrm{~Pb}$ and $\mathrm{Pd}_{1.1} / \mathrm{WO}_{2.72}$, which exhibit relatively high electrocatalytic activities towards formic acid oxidation, results in a lower peak potential for CO stripping. On the other hand, in the case of Pt-based bimetallic compounds, if the d-band center values are higher than those of pure $\mathrm{Pt}$, the $\mathrm{CO}$ adsorption energies on their surface are lower than that on the surface of pure Pt [49,52]. Hence, Au core-Pd shell (Au@Pd) structured nanoparticles (core-shell structures, such as a T core-M shell structure, will hereinafter be denoted as "T@M"), which have a high d-band center value [49], exhibit high CO tolerance, indicating that Au makes Pd CO tolerant $[49,53]$. In fact, density functional theory (DFT) calculations have revealed that the CO adsorption energy on $\mathrm{Pd} / \mathrm{Au}$ (111) surfaces is significantly lower than that on pure Pd [54]. Therefore, bimetallic Pd-Au shows high activity towards formic acid oxidation because of its high $\mathrm{CO}$ tolerance. However, Au@Pd bimetallic compounds hardly show enhanced catalytic activity [49,53]. Therefore, the d-band center values (i.e., CO adsorption energy on Pd) of Pd-based catalysts should be optimized.

Table 1. Mass activities (MA) at $0.3 \mathrm{~V}$ versus the reversible hydrogen electrode (RHE) of various Pd-based catalysts for formic acid oxidation and CO stripping.

\begin{tabular}{|c|c|c|c|c|}
\hline Catalyst & $\operatorname{MA}\left(\mathrm{A} \mathrm{mg}^{-1}{ }_{\mathrm{Pd}}\right)$ & $\begin{array}{c}\text { Concentration of } \\
\text { Formic Acid }\left(\mathrm{mol} \mathrm{L}^{-1}\right)\end{array}$ & $\begin{array}{c}\text { E for Peak Top of } \mathrm{CO} \\
\text { Stripping (V versus } \mathrm{RHE})\end{array}$ & References \\
\hline $\mathrm{Pd}$ & 0.35 & 0.1 & 1.00 & [46] \\
\hline Pd@Au & 0.52 & 3 & 0.872 & [53] \\
\hline $8 \mathrm{~nm} \mathrm{Pd}{ }_{0.5} \mathrm{Co}_{0.5}$ & $0.18^{\mathrm{a}}$ & 2 & - & {$[47]$} \\
\hline Pd nanosheets & $0.3^{\mathrm{a}}$ & 0.25 & - & [55] \\
\hline $\mathrm{Pd}-\mathrm{g}-\mathrm{C}_{3} \mathrm{~N}_{4}-\mathrm{rGO}-2$ & 1.02 & 0.5 & 0.96 & [58] \\
\hline $\mathrm{Pd}_{57} \mathrm{Ni}_{43}$ nanowires & 0.62 & 0.5 & - & [48] \\
\hline PdCu alloy multipods & 0.15 & 1 & 0.96 & [50] \\
\hline $\mathrm{PdAg} / \mathrm{Ti}_{0.5} \mathrm{Cr}_{0.5} \mathrm{~N}$ & 0.31 & 1 & - & [59] \\
\hline $\mathrm{Pd}_{0.57} \mathrm{Ni}_{0.13} \mathrm{Cu}_{0.30}$ & 0.48 & 0.5 & 0.92 & [49] \\
\hline
\end{tabular}


Hu et al. prepared Pd-based bi- and tri-metallic compounds, such as Ru@Pd, PdNi, PdCu, $\mathrm{PdNiCu}$ and $\mathrm{Au} @ \mathrm{Pd}$, and evaluated their electrocatalytic activity towards the electrooxidation of formic acid [49,60]. In addition, they also investigated the effect of the d-band center position (as determined by X-ray photoelectron spectroscopy) on their activity towards the electrooxidation of formic acid (Figure 2). The d-band center value of Pd-based materials can be tuned (for improving the catalytic activity) by forming PdCuNi trimetallic compounds. This indicates that Pd-based materials show electrocatalytic activity towards formic acid oxidation only at optimum d-band center values. This can be explained by the following reaction mechanism:

$$
\begin{gathered}
\mathrm{HCOOH}+\mathrm{Pd} \rightarrow \mathrm{HCOO}-\mathrm{Pd}+\mathrm{H}^{+}+\mathrm{e}^{-} \\
\mathrm{HCOO}-\mathrm{Pd} \rightarrow \mathrm{Pd}-\mathrm{H}+\mathrm{CO}_{2}
\end{gathered}
$$

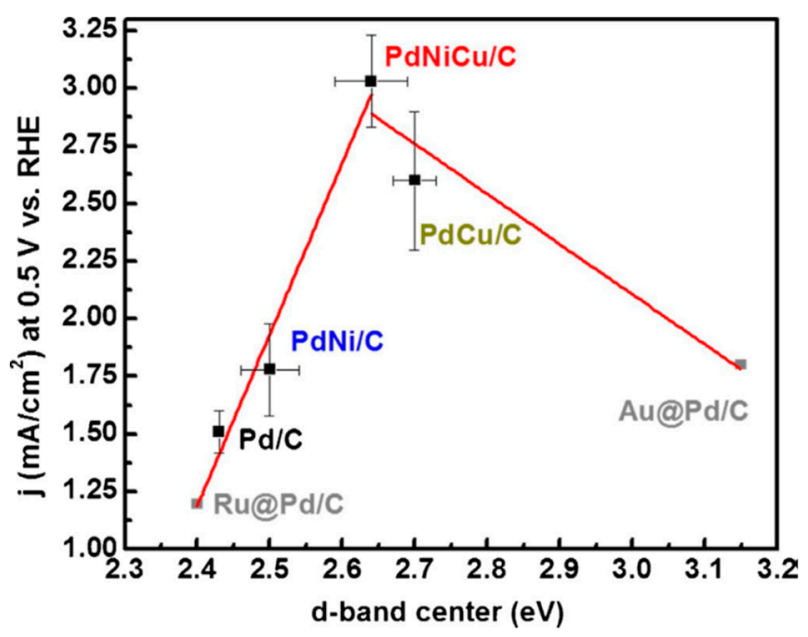

Figure 2. Relationship between the d-band center values and current densities of various Pd-based catalysts at $0.5 \mathrm{~V}$ (versus RHE). Reproduced with permission [49]. Copyright 2016, Elsevier.

In order to proceed via the direct pathway, $\mathrm{HCOO}_{\mathrm{ad}}$ should be formed on Pd (i.e., $\mathrm{HCOO}-\mathrm{Pd}$ ). Therefore, the strength of the $\mathrm{Pd}-\mathrm{O}$ bond is very important to realize the high catalytic activities of $\mathrm{Pd}$-based catalysts. When the d-band center of Pd is away from the Fermi level, the bond between Pd and the intermediate becomes weak. On the other hand, when the d-band center is significantly close to the Fermi level, the bond between Pd and the intermediate becomes strong. Therefore, Pd shows electrochemical activity towards formic acid oxidation at the optimum d-band center position.

It is well-known that the electrocatalytic activities (towards ORR and the oxidation of organic compounds) of Pd- and Pt-based materials are significantly affected not only by their electronic states but also by their crystal structures. For example, $\mathrm{Pt}_{3} \mathrm{Ni}$ (111) shows a much higher electrocatalytic activity towards ORR than $\mathrm{Pt}_{3} \mathrm{Ni}(100)$ and $\mathrm{Pt}_{3} \mathrm{Ni}$ (110). Interestingly, $\mathrm{Pt}_{3} \mathrm{Ni}$ (110), which has a d-band center value is $-2.70 \mathrm{eV}$, shows an ORR activity 2.5 times higher than that of $\mathrm{Pt}(111)$, which has a similar d-band center value $(-2.76 \mathrm{eV})$ [61]. This indicates that the electrochemical activities of $\mathrm{Pd}-$ and Pt-based catalysts are affected more by their secondary material and surface structures than their electronic states. Therefore, in order to develop Pd-based materials with high electrochemical activities, it is very important to create ideal surfaces and morphologies.

Electrocatalysts with morphology-dependent activity have been developed as novel active electrocatalysts. Yang and coworkers developed $\mathrm{Cu}-\mathrm{Pd}$ alloy multipods and evaluated their electrocatalytic activity towards formic acid oxidation [32]. These multipods showed high catalytic activities, as illustrated in Figure 3, because of the presence of a large number of active edges/corner atoms in their unique multipod structure. The $\mathrm{Cu}-\mathrm{Pd}$ alloy multipods were prepared by the galvanic replacement reaction between presynthesized $\mathrm{Cu}$-template nanoparticles and $\mathrm{Pd}^{2+}$ ion precursors. 
The electrocatalytic activities and electronic states of these $\mathrm{Cu}-\mathrm{Pd}$ alloy multipods were compared with those of the $\mathrm{Cu}-\mathrm{Pd}$ and $\mathrm{Pd}$ nanoparticles. The $\mathrm{Cu}-\mathrm{Pd}$ alloy multipods showed a lower d-band center than the $\mathrm{Cu}-\mathrm{Pd}$ and $\mathrm{Pd}$ nanoparticles, indicating that they show a higher electrocatalytic activity towards both the electrooxidation of formic acid and ORR, owing to their unique structure. The procedure proposed by Yang and coworkers for the synthesis of these multipods can be a promising approach to develop other bimetallic Pd- and Pt-based alloy multipods.
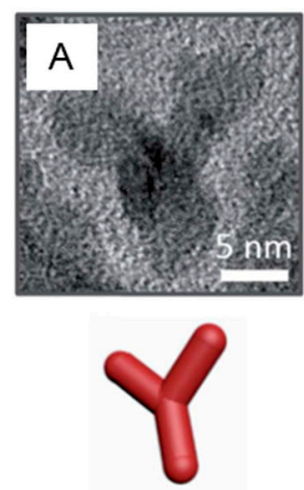

tripod
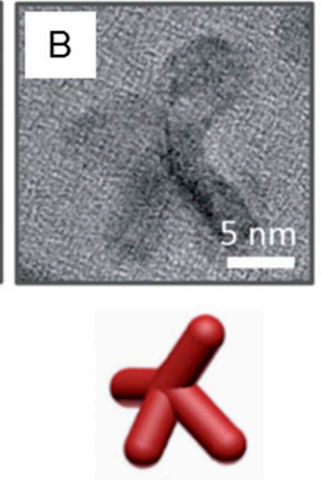

tetrapod
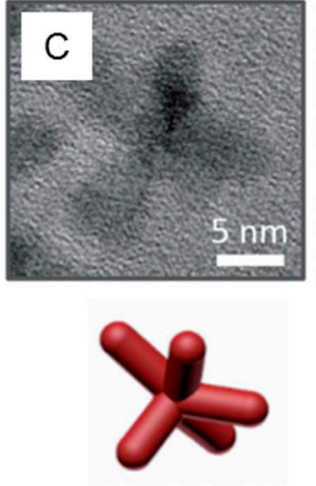

pentapod
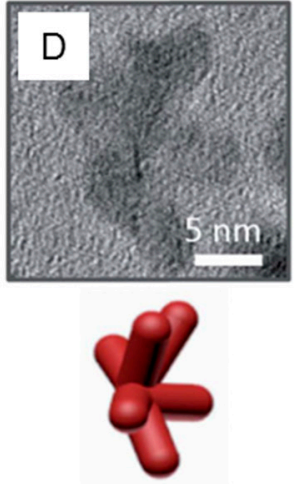

hexapod
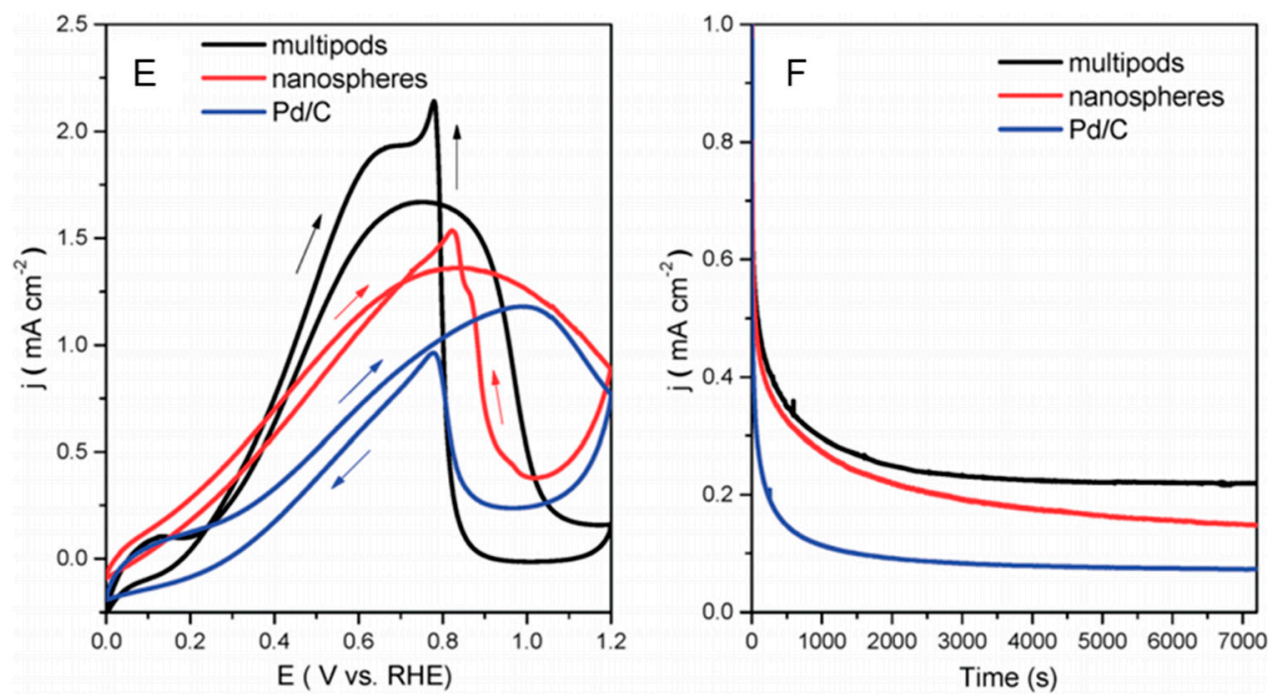

Figure 3. High-resolution (HR)-TEM images (A-D) of $\mathrm{Pd}-\mathrm{Cu}$ multipods with different pod numbers and the corresponding three-dimensional models. (E) Cyclic voltammograms and (F) chronoamperograms of $\mathrm{Pd}-\mathrm{Cu}$ multipods, $\mathrm{Pd}-\mathrm{Cu}$ nanoparticles and the $\mathrm{Pd} / \mathrm{C}$ catalyst at $0.4 \mathrm{~V}$ in $0.1 \mathrm{M} \mathrm{HClO}_{4}$ and $1 \mathrm{M}$ formic acid. Reproduced with permission [50]. Copyright 2016, Royal Chemical Society.

Over the past few years, electrochemically dealloyed Pt-based bimetallic compounds have gained immense attention as ORR electrocatalysts. For example, the removal of $\mathrm{Cu}$ (by electrochemical treatment) from $\mathrm{Pt}-\mathrm{Cu}$ results in the formation of a Pt-rich core-shell nanostructure, which shows a higher ORR activity than both nontreated $\mathrm{Pt}-\mathrm{Cu}$ and $\mathrm{Pt}$ nanoparticles [52,54]. A three to five layered Pt-rich shell, which can be obtained by a potential cycling of up to 5000 cycles, can enhance the ORR activity of Pt-based core-shell nanostructures [62,63]. The electrochemical treatment used for dealloying the secondary material in Pt-based bimetallic alloy catalysts plays an important role in enhancing their electrocatalytic activities.

Catalysts for formic acid electrooxidation should possess a high electrocatalytic activity and CO tolerance. In the case of Pt-based materials, structurally ordered intermetallic compounds, such as PtPb, 
$\mathrm{PtBi}, \mathrm{Pt}_{3} \mathrm{Ti}, \mathrm{Pt}_{3} \mathrm{Hf}$ and $\mathrm{Pt}_{3} \mathrm{Ta}$, exhibit a high $\mathrm{CO}$ tolerance because of their electronic efficiency, including the d-band center $[52,64,65]$. Herein, we have reviewed ordered intermetallic $\mathrm{Pd}_{3} \mathrm{~Pb}$ electrocatalysts for formic acid oxidation [31]. Figure 4 shows the electrocatalytic activity towards the formic acid oxidation of dealloyed ordered intermetallic $\mathrm{Pd}_{3} \mathrm{~Pb}$. The electrochemical treatment of intermetallic $\mathrm{Pd}_{3} \mathrm{~Pb}$ results in the formation of an ordered intermetallic $\mathrm{Pd}_{3} \mathrm{~Pb}$ core with a Pd-enriched surface (i.e., $\mathrm{Pd}_{3} \mathrm{~Pb} @ \mathrm{Pd}$ ). The first and second oxidation peaks for Pt and Pd correspond to the direct and $\mathrm{CO}$ oxidation pathways, respectively. On the other hand, no secondary oxidation peak was observed in the case of ordered intermetallic $\mathrm{Pd}_{3} \mathrm{~Pb}$, indicating that $\mathrm{CO}_{2}$ is formed directly on the surface of intermetallic $\mathrm{Pd}_{3} \mathrm{~Pb}$, without dehydration and $\mathrm{CO}$ adsorption. The $\mathrm{CO}$ binding energy of $\mathrm{Pd}_{3} \mathrm{~Pb}(111)$ $(1.05 \mathrm{eV})$ is lower than that of $\mathrm{Pd}(111)(1.29 \mathrm{eV})$. This is consistent with the predictions made on the basis of the measured and calculated d-band center values. This suggests that ordered intermetallic $\mathrm{Pd}_{3} \mathrm{~Pb} / \mathrm{CB}$ is more tolerant to $\mathrm{CO}$ adsorption and hence shows a higher formic acid electrooxidation than $\mathrm{Pd}$ NPs/CB. The higher electrocatalytic activity of intermetallic $\mathrm{Pd}_{3} \mathrm{~Pb}$ can be attributed to the electrochemical dealloying process.
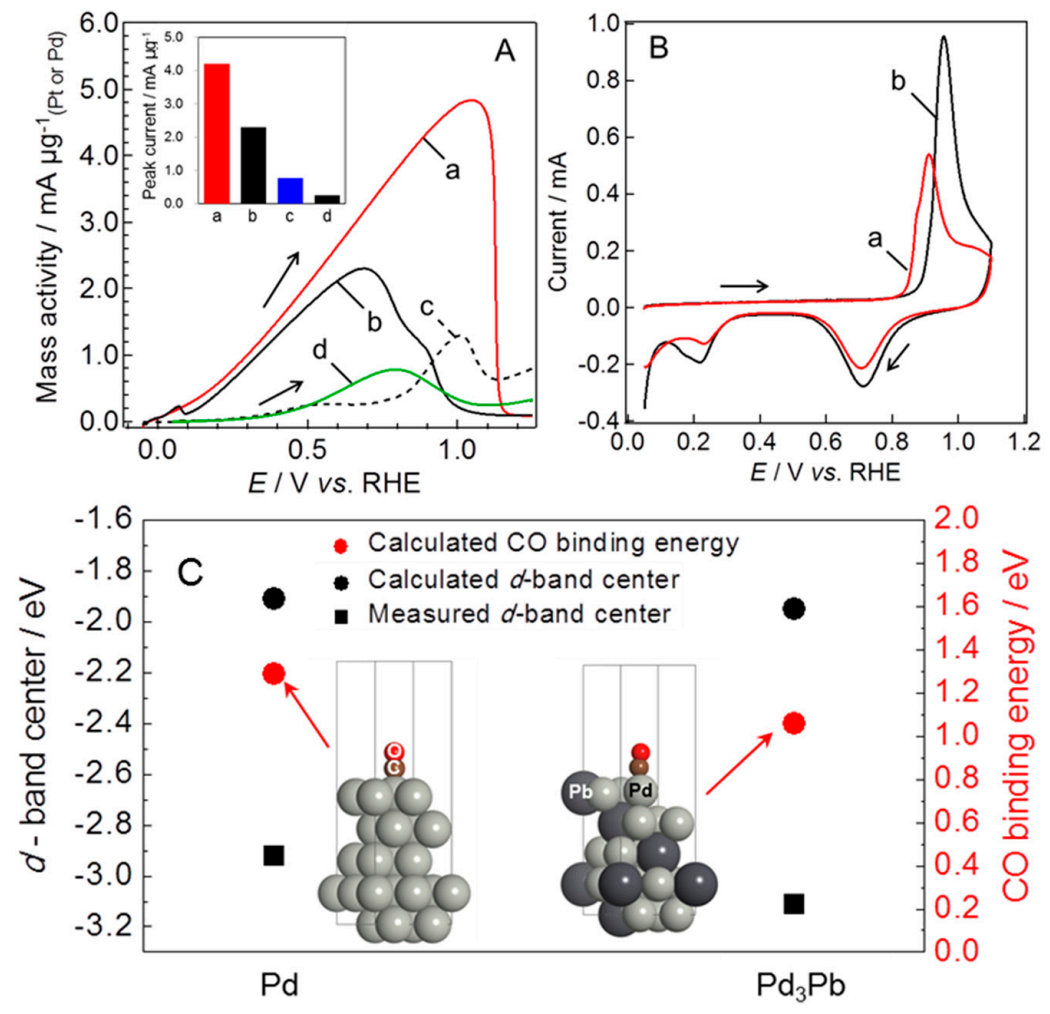

Figure 4. (A) Linear sweep voltammograms for oxidation of formic acid on (a) intermetallic $\mathrm{Pd}_{3} \mathrm{~Pb}$ electrochemically treated for 50 cycles, (b) Pd, (c) Pt and (d) Pt-Ru alloy. (B) Cyclic voltammograms for CO stripping over (a) $\mathrm{Pd}_{3} \mathrm{~Pb}$ electrochemically treated for 50 cycles and (b) $\mathrm{Pd}$. (C) Experimentally measured (black square) and density functional theory (DFT) calculated (black circle) d-band centers for $\mathrm{Pd}$ and intermetallic $\mathrm{Pd}_{3} \mathrm{~Pb}$ structures. Reproduced with permission [31]. Copyright 2017, American Chemical Society.

In order to improve the electrochemical activity and durability of Pt- and Pd-based catalysts, electrochemically stable supporting materials, which modify the electronic structure of the catalysts, are extensively used $[66,67]$. However, when carbon nanotubes (CNTs) are used as the supporting material for Pd nanoparticles (Pd/CNT), no significant improvement is observed in formic acid electrooxidation and CO stripping [68].

Recently, Raj et al., developed a novel electrocatalyst using unzipped (Uz) single-walled CNTs (SWCNTs) as a support for Pd nanoparticles. The unzipped SWCNTs were prepared via a one-pot 
synthesis method [69] without using harsh oxidizing agents. The Uz-CNT-Pd catalyst that was prepared showed a significantly higher formic acid electrochemical oxidation activity than the SWCNT/Pd and unsupported Pd nanoparticles (Figure 5). The onset potential for CO electrooxidation over Uz-CNT-Pd was $-80 \mathrm{mV}$ lower than that over Pd nanoparticles. This indicates that CO oxidation was facile in the case of Uz-CNT-Pd. In addition, the electrochemical surface area (as calculated from the magnitude of the peak area for CO oxidation) of Uz-CNT-Pd was approximately 2.5 times higher than that of the Pd nanoparticles. The electronic interaction between the unzipped SWCNTs and Pd nanoparticles facilitated the electron transfer required for the electrooxidation of the formic acid. We believe that this approach can be used to develop graphitic carbon-coated electrocatalytically active Pd- and Pt-based materials.
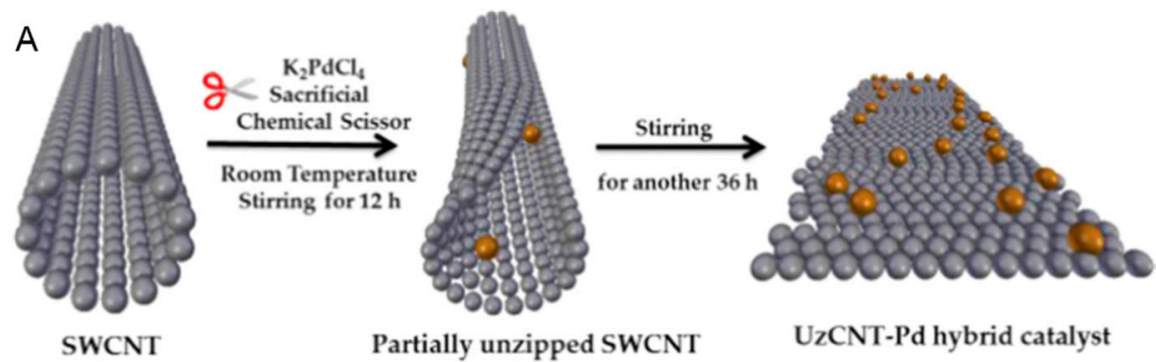

Partially unzipped SWCNT

UzCNT-Pd hybrid catalyst

- Pd nanoparticle
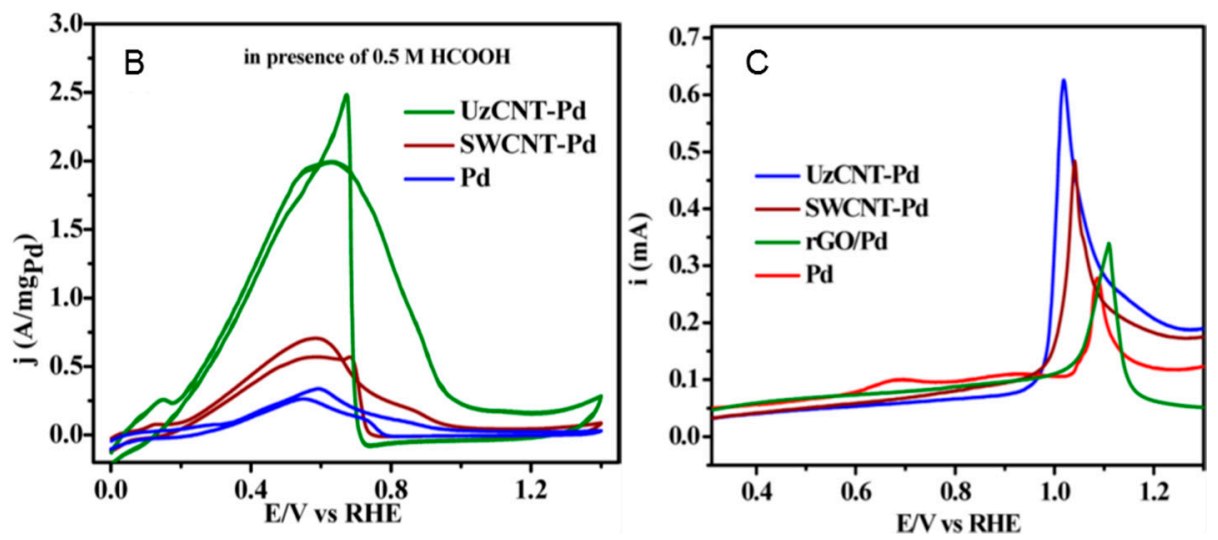

Figure 5. (A) Schematic illustration of the unzipping of single-walled carbon nanotubes (SWCNTs). (B) Cyclic voltammograms for formic acid electrooxidation and (C) anodic sweep voltammograms for CO stripping. Reproduced with permission [69]. Copyright 2018, American Chemical Society.

\section{ORR}

\subsection{ORR on Metal Catalysts}

ORR, which uses Pt as the cathode catalyst, are one of the key types of reactions in the field of PEFCs. However, the slow reaction kinetics for ORR at the cathode and the use of the expensive Pt electrocatalyst limit the widespread commercialization of PEFCs. In acidic solutions, Pt is the best ORR electrocatalyst because of the optimal adsorption energy between molecular oxygen and $\mathrm{Pt}$ atoms. However, in order to reduce the cost of PEFCs, it is imperative to develop low-cost alternatives to Pt-based electrocatalysts. Hence, various efforts have been made to develop cost-effective electrocatalysts (using relatively abundant elements) for PEFCs. In his review, Raj discussed various Pt-free catalysts using non-precious transition metals, metal nitrides, carbides and nanoscale carbon-based metal-free electrocatalysts [5]. According to Hammer and Stamenkovic et al. [70,71], the ORR electrocatalytic activity of metal catalysts is strongly affected by their electronic states, in particular, the position of the d-band center in the valence band, which is determined using DFT calculations and ultraviolet photoemission spectroscopy. Figure 6 shows the relationship between 
the d-band center value of various metals and their ORR activities under alkaline conditions, as reported by Lama and coworkers [72]. As can be observed from the figure, a volcano-type relationship exists between the d-band center values of the pure metal catalysts and their electrocatalytic activities towards ORR.

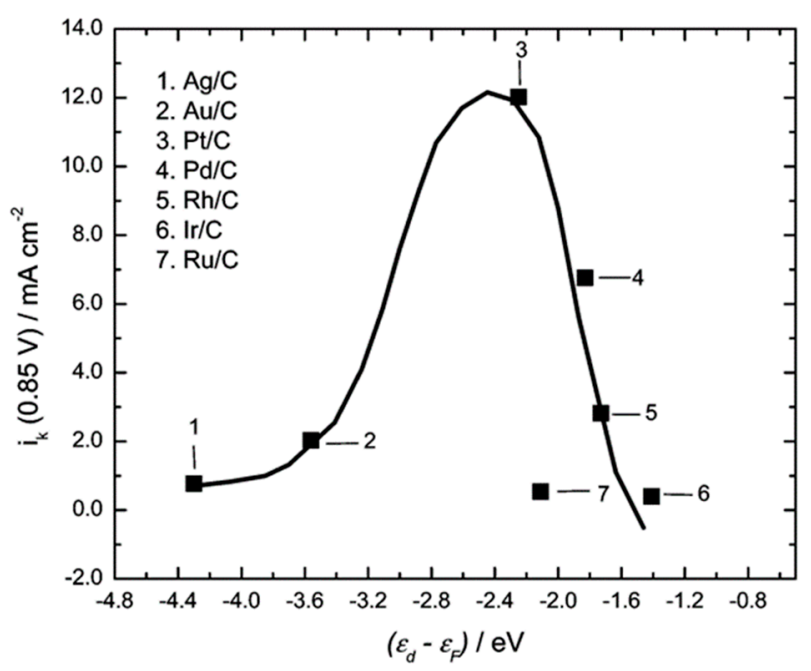

Figure 6. Kinetic current $\left(\mathrm{i}_{\mathrm{k}}\right)$ at $0.80 \mathrm{~V}$ versus $\mathrm{RHE}$ for $\mathrm{O}_{2}$ reduction on carbon-supported metal nanoparticles in a $0.1 \mathrm{~mol} \mathrm{~L}^{-1} \mathrm{NaOH}$ solution as a function of the metal d-band center. Reproduced with permission [72]. Copyright 2007, American Chemical Society.

\subsection{ORR on Pd-Based Catalysts in Alkaline Media}

$\mathrm{Pd}$ is a promising electrocatalyst that could act as an alternative for $\mathrm{Pt}$ for alkaline ORR because its ORR activity is comparable to that of Pt in alkaline media (Table 2). Recently, we reported that the ORR activity of Pd-M (M = Ni, Co, and Fe), prepared by electrochemical potential cycles, was higher than that of $\mathrm{Pd}$ after 1500 cycles because the d-band center value of $\mathrm{Pd}-\mathrm{M}$ was reduced relative to pure Pd, based on hard X-ray photoemission spectroscopy and computational calculations [73]. Several researchers have also reported that ordered intermetallic $\mathrm{Pd}_{3} \mathrm{~Pb}$ has significantly increased electrocatalytic activity for ORR in alkaline media [8,74-77]. Electrocatalytic activity over intermetallic $\mathrm{Pd}_{3} \mathrm{~Pb}$ strongly depends on the nanoparticle morphology. For ORR in alkaline media, spherically ordered intermetallic $\mathrm{Pd}_{3} \mathrm{~Pb}$ nanoparticles were reported first by Cui et al. in 2016 [74]. The electrocatalytic activities for ORR over ordered intermetallic $\mathrm{Pd}_{3} \mathrm{~Pb}$, having nanowire, tripod, and nanoplate morphologies, reported by Shi et al., Huang et al. and Luo et al., respectively, were more than three times higher than that of the spherical $\mathrm{Pd}_{3} \mathrm{~Pb}$ nanoparticles [8,75-77]. Huang et al. proposed that a coupled s-p-d exchange effect on the (110) facets of the $\mathrm{Pd}_{3} \mathrm{~Pb}$ tripods improves the ORR catalytic activity in alkaline media. According to their first-principle calculations, the charge exchange between the $\mathrm{Pd}-4 \mathrm{~d}$ and $\mathrm{Pb}-(\mathrm{sp})$ regions on the $\mathrm{Pd}_{3} \mathrm{~Pb}$ tripods (110) facet results in a $\mathrm{Pd}-\mathrm{Pb}$ local bonding unit that has an orbital configuration similar to that of $\mathrm{Pt}$ [75]. This result indicates that the ordered intermetallic $\mathrm{Pd}_{3} \mathrm{~Pb}$ can be used as an alternative catalyst to $\mathrm{Pt}$. $\mathrm{Pd}$ is an excellent electrocatalyst for methanol oxidation in alkaline media, implying that methanol is easily adsorbed on the Pd surface, resulting in reduced ORR activity in alkaline media. Therefore, Pd-based electrocatalysts with tolerance for methanol adsorption must be developed. Recently, many researchers have developed Pd-based electrocatalysts with no electrocatalytic activity towards methanol oxidation in alkaline media. Lin et al. reported that ordered intermetallic $\mathrm{Pd}_{3} \mathrm{~Pb}$ has high ORR selectivity in the presence of methanol in alkaline electrolytes [8]. Chen et al. have demonstrated a novel approach for the preparation of Au-nanowire-@Pd bimetallic nanohybrids, functionalized by polyethylenimine (PEI), which have increased electrocatalytic activity towards ORR and increased methanol tolerance when compared with Pt electrocatalysts in alkaline media [78]. According to their report, PEI exhibits a methanol-phobic 
behavior. Therefore, this result shows that highly active Pd-based materials for alkaline ORR can exhibit a methanol tolerance because of PEI functionalization.

Table 2. MA at $0.9 \mathrm{~V}$ (versus RHE) and half-wave potentials $\left(E_{1 / 2}\right)$ for ORR by various Pd-based catalysts in an $\mathrm{O}_{2}$-saturated $0.1 \mathrm{M} \mathrm{KOH}$ aqueous solution.

\begin{tabular}{|c|c|c|c|}
\hline Catalyst & $\mathrm{MA}$ at $0.90 \mathrm{~V} / \mathrm{A} \mathrm{mg}^{-1} \mathrm{Pd}$ & $E_{1 / 2} / \mathrm{V}$ versus $\mathrm{RHE}$ & References \\
\hline $\mathrm{Pd}_{3} \mathrm{~Pb}$ nanoparticles & 0.17 & 0.92 & [74] \\
\hline $\mathrm{Pd}_{3} \mathrm{~Pb}$ nanowires (NWs) & 0.61 & 0.92 & [8] \\
\hline $\mathrm{Pd}_{3} \mathrm{~Pb}$ tripods & 0.56 & 0.91 & [75] \\
\hline $\mathrm{Pd}_{3} \mathrm{~Pb}$ square nanoplates & 0.62 & 0.91 & [76] \\
\hline $\mathrm{Pd}_{3} \mathrm{~Pb}$ square nanoplates & 0.78 & 0.88 & {$[77]$} \\
\hline $\mathrm{Pd} / \mathrm{W}_{18} \mathrm{O}_{49}$ & 0.22 & 0.88 & [79] \\
\hline Pd-B & 0.15 & 0.88 & [80] \\
\hline Pd@Pd-Ni MWCNTs & 0.071 & 0.87 & [78] \\
\hline Au NWs@Pd@PEI & 0.30 & 0.90 & [81] \\
\hline $\mathrm{Pd}_{3} \mathrm{Fe}$ & 0.097 & 0.89 & [82] \\
\hline
\end{tabular}

\subsection{Electrocatalytic Activity of Pd-Based Materials towards ORR in Acidic Media}

Metals with high d-band center values, such as $\mathrm{Ru}$, Ir and Rh, show low electrocatalytic activities because of the high adsorption strength of $\mathrm{O}_{2}$. These metals can easily dissociate the $\mathrm{O}-\mathrm{O}$ bond. However, this results in a high coverage by oxygenated intermediates, which are slowly desorbed. On the other hand, in the case of metals with d-band centers away from the Fermi level (i.e., a low-band center), such as $\mathrm{Ag}$ and $\mathrm{Au}$, it is difficult for oxygen and the metal catalyst to react, which results in poor electrocatalytic activity. Among all pure elements, $\mathrm{Pt}$ has the ideal d-band center for ORR under acidic conditions. Since the electronic state of $\mathrm{Pt}$ can be easily modified by alloying, various efforts have been made over the past few decades to develop Pt-based electrocatalysts. Stamenkovic and coworkers have shown that a volcano-type relationship exists between the ORR activity and d-band center values of $\mathrm{Pt}$ catalysts obtained by alloying with transition metals such as $\mathrm{Co}, \mathrm{Ni}$, $\mathrm{Fe}$ and $\mathrm{Ti}$ [10]. Mentus and coworkers investigated the relationship between the d-band centers of bulk alloys of $\mathrm{Pt}$ with transition metals $(\mathrm{M}=\mathrm{Au}, \mathrm{Pd}, \mathrm{Cu}, \mathrm{Bi}$ and $\mathrm{Pb})$ and the alloy composition. They reported that in $\mathrm{Pt}-\mathrm{M}$ bimetallic compounds with a 1:1 ratio, $\mathrm{Pb}$ and $\mathrm{Bi}$ contribute to the decrease in the d-band center value [83]. Although significant progress has been made in the field of PEFCs, the high cost of Pt-based catalysts is the major limitation to the widespread commercialization of PEFCs. Therefore, efficient and low-cost alternatives to Pt-based catalysts should be developed. Various studies have been carried out to develop ORR electrocatalysts using low-cost materials.

Pd-based catalysts have gained immense attention as potential alternatives to Pt for ORR. This is because with the exception of $\mathrm{Pt}$, $\mathrm{Pd}$ shows the highest electrocatalytic activity towards ORR. Therefore, various Pd-based compounds with high electrocatalytic activity towards ORR in acidic media have been developed (Table 3). In acidic media, ORR proceeds via the four- and two-electron pathways, as shown below:

$$
\begin{aligned}
& \mathrm{O}_{2}+4 \mathrm{H}^{+}+4 \mathrm{e}^{-} \rightarrow 2 \mathrm{H}_{2} \mathrm{O} \\
& \mathrm{O}_{2}+2 \mathrm{H}^{+}+2 \mathrm{e}^{-} \rightarrow \mathrm{H}_{2} \mathrm{O}_{2}
\end{aligned}
$$

The reaction mechanism of ORR strongly depends on the electrode materials, electrolyte and electrocatalyst. It is well known that $\mathrm{Pt}$ and Pd can induce a four-electron reduction in ORR. On the other hand, the production of $\mathrm{H}_{2} \mathrm{O}_{2}$ by a two-electron reduction of oxygen also possesses a significant advantage. So far, there are several reports on the synthesis of $\mathrm{H}_{2} \mathrm{O}_{2}$ through ORR. Pt polycrystalline with ammonium ions [84], $\mathrm{Pt}-\mathrm{Hg}$ [85], $\mathrm{Pd}-\mathrm{Hg}$ [85,86] $\mathrm{Pd}-\mathrm{Au}$ [87] and $\mathrm{Au}$ [88] have been used as electrocatalysts for the synthesis of $\mathrm{H}_{2} \mathrm{O}_{2}$. In hydrogen-oxygen fuel cells, the four-electron transfer from $\mathrm{ORR}$ to $\mathrm{H}_{2} \mathrm{O}$ is highly preferred because of its high-power generation. 
Table 3. MA at $0.9(0.85) \mathrm{V}$ versus RHE and $\mathrm{E}_{1 / 2}$ for ORR of various Pd-based catalysts in an $\mathrm{O}_{2}$-saturated $\mathrm{HClO}_{4}$ aqueous solution.

\begin{tabular}{|c|c|c|c|}
\hline Catalyst & MA at $0.90(0.85) \mathrm{V} / \mathrm{A} \mathrm{mg}^{-1} \mathrm{Pt}$ or Pd & $E_{1 / 2} / V$ versus $R H E$ & References \\
\hline $\mathrm{Pt}$ & $0.21-0.23$ & about 0.826 & [89-91] \\
\hline $\mathrm{Pd}$ & $(0.03-0.025)$ & about 0.78 & [92] \\
\hline PdNiCo NPs & $0.047(0.137)$ & 0.86 & [92] \\
\hline $\mathrm{PdCu}$ & $0.041(0.156)$ & 0.85 & [93] \\
\hline $\mathrm{PdCu}_{3}$ at $600^{\circ} \mathrm{C}$ & $(0.10)^{\mathrm{a}}$ & 0.82 & [94] \\
\hline $\mathrm{PdCu}_{3}$ dealloyed & 0.047 & 0.88 & [95] \\
\hline $\mathrm{Pd}_{8} \mathrm{CoZn}$ & $0.019(0.141)$ & 0.84 & [96] \\
\hline NP-Pd ${ }_{0.75} \mathrm{Cr}_{0.25}$ & 0.158 & 0.89 & [97] \\
\hline PdCu alloy multipods & - & 0.819 & [50] \\
\hline $\mathrm{C}-\mathrm{fct}-\mathrm{Fe}_{46} \mathrm{Pd}_{54}$ & 0.1 & 0.87 & [98] \\
\hline $\mathrm{v}-\mathrm{PdCuCo}$ & 0.175 & 0.91 & [99] \\
\hline $\mathrm{Pd}_{3} \mathrm{Fe}$ & $(0.12)$ & 0.80 & [100] \\
\hline $\mathrm{Pd}_{3} \mathrm{Fe}$ & $(0.6)$ & 0.85 & [101] \\
\hline
\end{tabular}

In the case of ORR in acidic conditions, the electrocatalytic activity of Pd has a significantly lower electrocatalytic activity than that of pure Pt because Pd has a higher d-band center value than $\mathrm{Pt}$, which results in the strong adsorption of oxygen during the initial stage of the ORR. Thus, to develop Pd-based electrocatalysts with high electrocatalytic activity towards ORR in acidic media, it is necessary to control their electronic crystal structures and properties. Recently, bimetallic Pd alloy compounds such as $\mathrm{Pd}-\mathrm{Fe}, \mathrm{Pd}-\mathrm{Co}, \mathrm{Pd}-\mathrm{Ni}$ and $\mathrm{Pd}-\mathrm{Cu}$ have gained immense attention as ORR catalysts because their activities are comparable to those of Pt and Pt-based catalysts [92-101].

\subsection{The Development of Electrocatalysts for ORR Based on Theoretical Calculations}

Lihui proposed a criterion (based on the negative alloy formation energy, negative surface segregation energy of Pd and oxygen binding ability) for screening Pd-based bimetallic electrocatalysts for ORR. The values of alloy formation energy $\left(\Delta E_{\text {alloy }}\right)$, surface segregation energy $\left(\Delta E_{\text {segregation }}\right)$ and oxygen binding energy $\left(\Delta E_{\mathrm{O}}\right)$ of Pd-based bimetallic alloy catalysts, obtained via numerical simulations, indicated that elements such as $\mathrm{Fe}, \mathrm{V}, \mathrm{Zn}, \mathrm{Nb}, \mathrm{Mo}$, Ta and $\mathrm{W}$ enhance the ORR activity of the catalysts [102], as shown in Figure 7. However, the formation energies of Pd-Mo and Pd-W alloys are almost zero, indicating that the stability of these alloys is poor. Pd-Fe shows excellent electrocatalytic activity towards ORR in terms of the three factors (mentioned above), as predicted by DFT calculations. Although there are various reports on the effect of alloying elements such as Co, $\mathrm{Cu}, \mathrm{Cr}, \mathrm{Fe}$ and $\mathrm{Ni}$ on the ORR activity of Pd-based catalysts, the effect of $\mathrm{Zn}, \mathrm{Nb}$ and Ta should also be investigated.

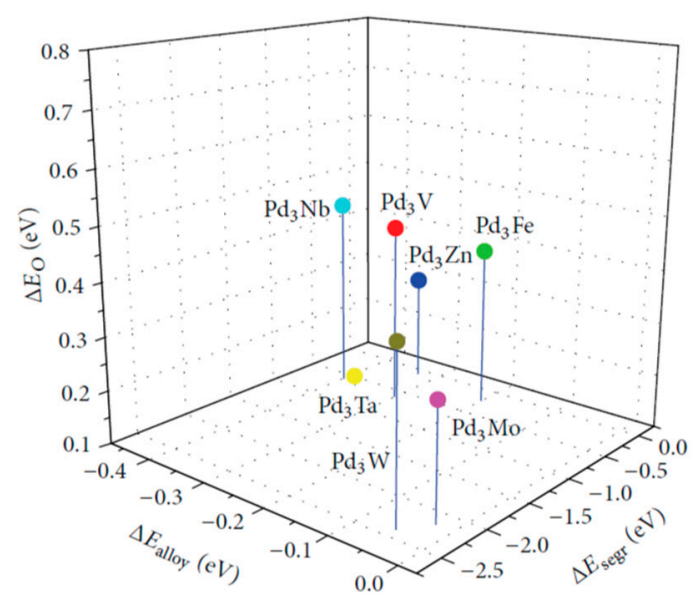

Figure 7. Three-dimensional optimization: High stability and ORR catalytic activity [102]. 
Computational studies have shown that $\mathrm{Pd}-\mathrm{Cu}$ catalysts show ORR activity comparable to that of $\mathrm{Pt}$. There are several possible structures for $\mathrm{Pd}-\mathrm{Cu}$ electrocatalysts, such as $\mathrm{B}_{2}, \mathrm{~L} 1_{2}, \mathrm{~L} 1_{0}, \mathrm{~L} 1_{1}$-nonlayered and $\mathrm{L1}_{1}$-layered [103]. The experimental results reported by various researchers have revealed that $\mathrm{Cu}$-doped Pd electrocatalysts exhibit high electrocatalytic activities [50,93-95]. Numerical simulations have revealed that body-centered cubic structured $\mathrm{Pd}-\mathrm{Cu}$ shows poor catalytic activity, while catalysts with a layered $\mathrm{L}_{1}$ surface show significantly faster ORR kinetics than pure Pd. On the other hand, $\mathrm{Pd}-\mathrm{Cu}$ bimetallic catalysts with structurally dependent activities have been also been developed. Ordered intermetallic B2-type structured $\mathrm{Pd}-\mathrm{Cu}$ nanoparticles have been prepared by a seed-mediated co-reduction method [93]. Ordered $\mathrm{Pd}-\mathrm{Cu} \mathrm{B}_{2}$ nanoparticles show higher ORR activity than disordered $\mathrm{Pd}-\mathrm{Cu}$ nanoparticles. However, since the surface structure of bimetallic compounds can change under acidic conditions, it is necessary to consider a secondary material-free surface structure.

In one of our studies, we developed structurally ordered intermetallic electrocatalysts with excellent ORR activity in acidic media. Figure 8 shows the binding energy strength between the electrocatalyst surface and the dissociated $\mathrm{O}$, as predicted by DFT calculations. The DFT calculations revealed that Pd-based catalysts can show electrocatalytic activities higher than those of $\mathrm{Pt}$ and Pt-based compounds. Interestingly, the binding energy between the dissociated $\mathrm{O}$ atoms and the $\mathrm{Pd}$ sites in $\mathrm{PdCu}_{3}$ decreased significantly after electrochemical dealloying (i.e., the activity was increased by the electrochemical treatment). The binding energy of the dissociated $\mathrm{O}$ atoms $(4.36 \mathrm{eV})$ on electrochemically dealloyed $\mathrm{PdCu}_{3}$ is similar to that of $\mathrm{Pt}_{3} \mathrm{Ni}$ (111) [104]. However, the measured (on the basis of the onset and half-wave potentials) ORR electrocatalytic activity decreased in the following order: $\mathrm{Pt}>$ dealloyed $\mathrm{PdCu}_{3} \mathrm{NPs} / \mathrm{CB}>\mathrm{Pd}$ NPs $/ \mathrm{CB}$. The difference between the ORR activities (measured using DFT calculations) of the dealloyed $\mathrm{PdCu}_{3}$ and $\mathrm{Pt}$ can be attributed to the difference in the number of their active reaction sites [95]. This study demonstrated that by carrying out electrochemical dealloying and modifying the electronic state of Pd-based electrocatalysts, electrochemical activity comparable to that of Pt and Pt-based electrocatalysts can be achieved.

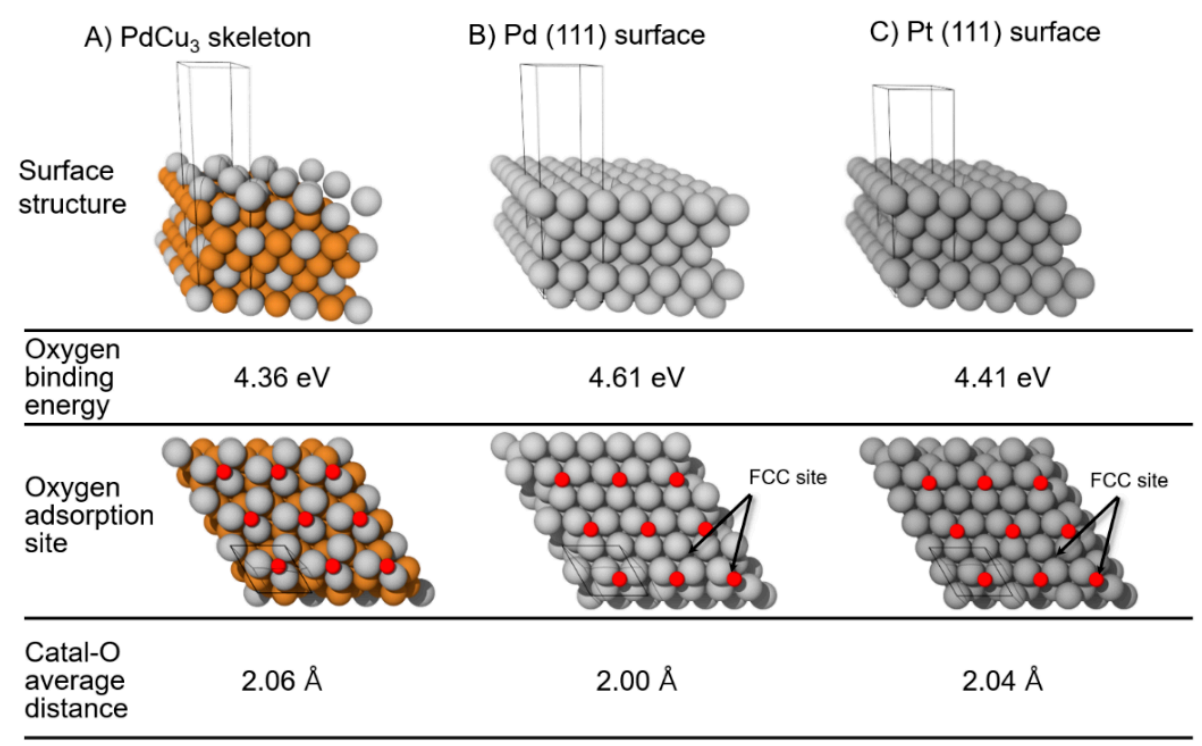

Figure 8. Schematic illustration of "Cu-free surface structures", which were formed by electrochemical dealloying. Reproduced with permission [95]. Copyright 2018, Royal Chemical Society.

It is well-known that the ORR activity of Pt- and Pd-based electrodes significantly depends on their crystal structures. For example, Hoshi and coworkers evaluated the ORR activity of low-index faceted Pd, such as Pd (100), Pd (110) and Pd (111). The ORR activity increased in the following order: $\mathrm{Pd}(110)<\mathrm{Pd}(111)<\mathrm{Pd}(100)$. This trend is opposite to that shown by $\mathrm{Pt}$ [105]. In particular, the ORR activity of $\mathrm{Pd}(100)$ is three times higher than that of $\mathrm{Pt}(110)$, which shows the highest activity among the low-index facets of Pt. Meku and coworkers reported that ordered intermetallic $\mathrm{Pd}_{3} \mathrm{Fe}$ 
nanoparticles, in which $\mathrm{Pd}_{3} \mathrm{Fe}$ has a super lattice structure ( $\mathrm{Cu}_{3} \mathrm{Au}$ type structure), show a much higher electrocatalytic activity towards ORR and durability than pure $\mathrm{Pd}$ and atomically disordered $\mathrm{Pd}-\mathrm{Fe}$ (FCC type structure) [106]. The dissolution of Pd under acidic conditions reduces the electrode stability of Pd and Pd-based compounds and consequently can decrease their ORR activities.

\subsection{The Development of Electrocatalysts with Simultaneously Improved Activity and Durability}

Wang and coworkers prepared Au-modified Pd-based ternary nanocatalysts $\left(\mathrm{Au}-\mathrm{Pd}_{6} \mathrm{CoCu}\right)$ using the spontaneous replacement method, as shown in Figure 9. These catalysts showed durability comparable to that of Pt. The Au-modified Au- $\mathrm{Pd}_{6} \mathrm{CoCu}$ electrode showed higher ORR activity (comparable to that of pure $\mathrm{Pt}$ ) than pure $\mathrm{Pd}$. In addition, during the durability test (in which the catalysts were subjected to potential cycles), $\mathrm{Au}-\mathrm{Pd}_{6} \mathrm{CoCu}$ showed a much lower MA loss (around 16\%) [92] than the commercially available $\mathrm{Pt}(32 \%)$ [107]. Only a trace amount of $\mathrm{Au}(\mathrm{Pd}: \mathrm{Au}=100: 1)$ is required to enhance the durability (for ORR) of Pd-based electrocatalysts. Wang et al. also demonstrated that trimetallic PdCuAu nanothorn assemblies have a large durability in acidic media because of their special morphology and the presence of $\mathrm{Au}$ [108]. Thus, this approach can be used to develop Pd-based electrocatalysts with a durability higher than that of $\mathrm{Pt}$ and state-of-the-art Pt-based compounds.

A
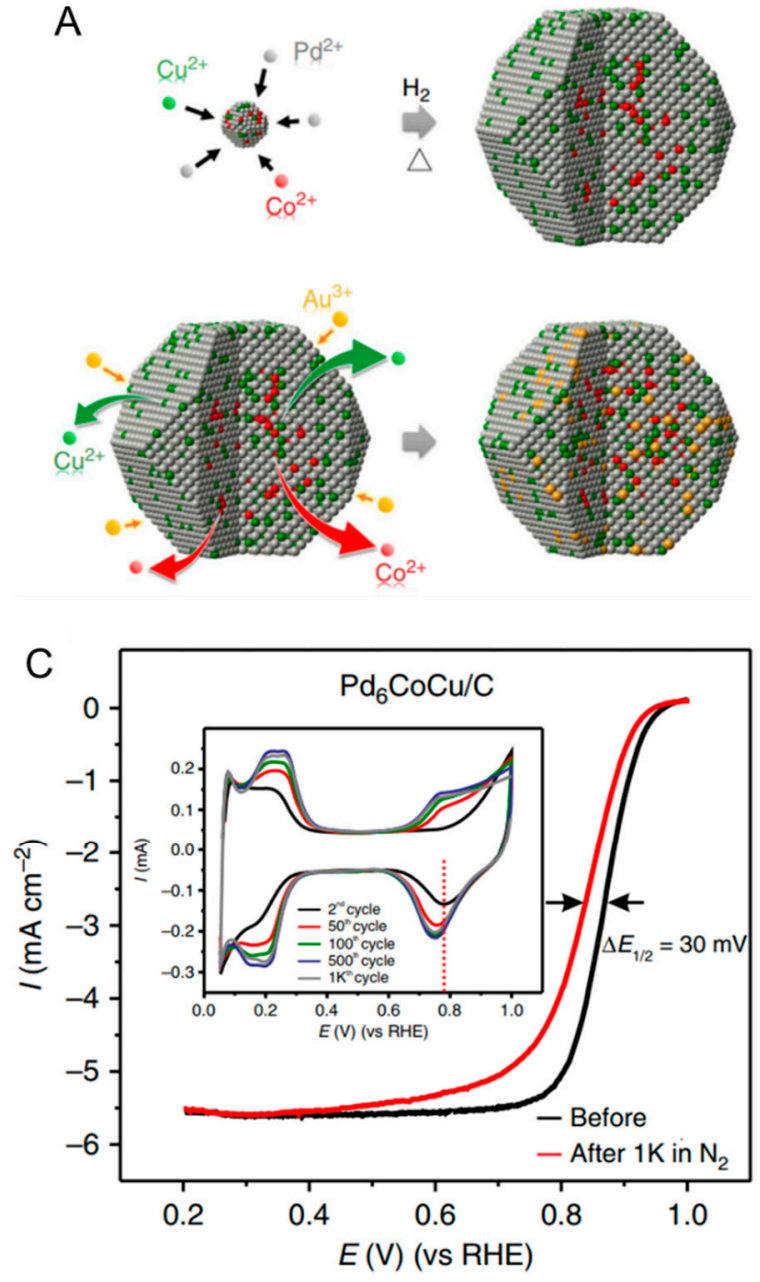
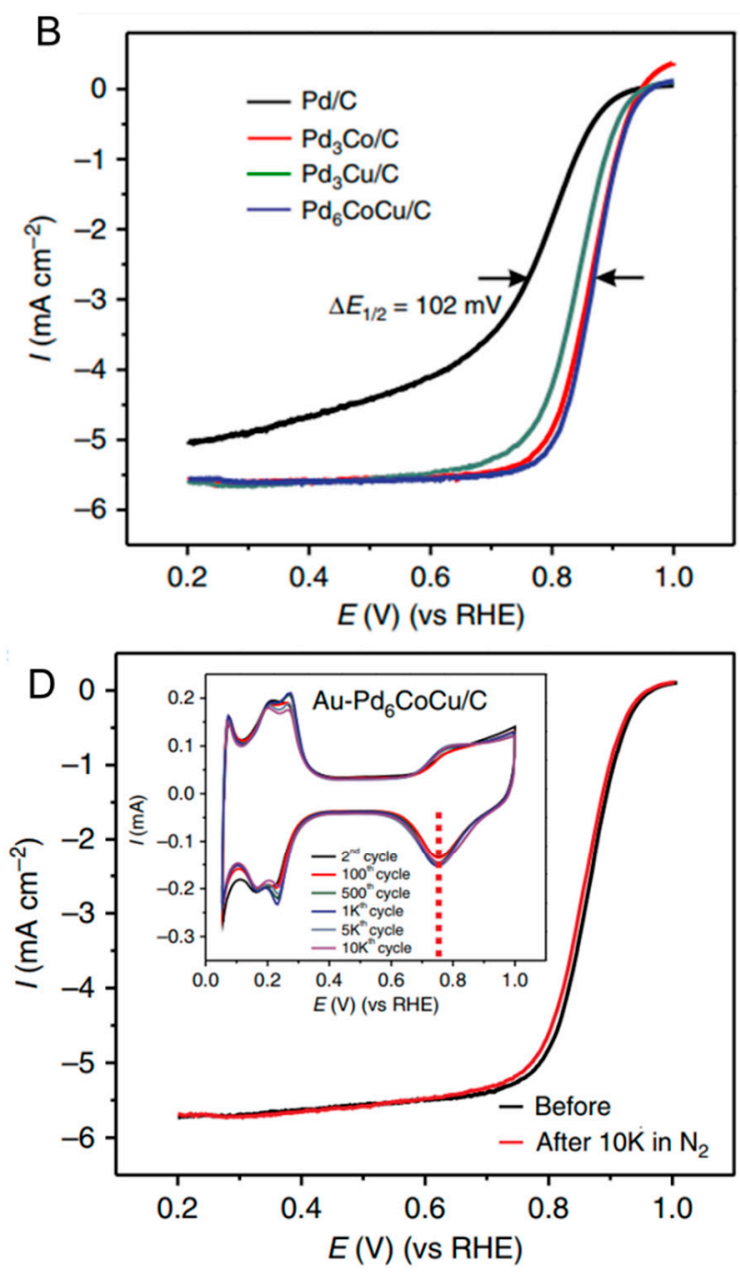

Figure 9. (A) Schematic of the preparation of Au-doped ternary PdCoCu. (B) Comparison of ORR polarization curves of various Pd-based catalysts in an $\mathrm{O}_{2}$-saturated $0.1 \mathrm{M} \mathrm{HClO}_{4}$ solution with a sweep rate of $5 \mathrm{mV} \mathrm{s}^{-1}$. (C) Anodic sweep voltammograms for ORR on $\mathrm{Pd}_{6} \mathrm{CoCu} / \mathrm{C}$ before and after 1000 potential cycles, and (D) the anodic sweep voltammograms for ORR on $\mathrm{Au}-\mathrm{Pd}_{6} \mathrm{CoCu} / \mathrm{C}$ before and after 10,000 potential cycles [92]. 
Electrocatalysts (for ORR) for DMFCs should also be methanol tolerant under acidic conditions, as methanol is used as a common fuel for these fuel cells. Therefore, for the commercialization of DMFCs, the ORR activity of the electrocatalyst should not be affected by the presence of methanol (which is mixed by the methanol crossover process) in the electrolyte. In the case of Pt electrocatalysts, the overpotential towards ORR under a methanol environment significantly increases to approximately $200 \mathrm{mV}$ because methanol blocks hinder the ORR. The decrease in the ORR electrocatalytic activity of $\mathrm{Pt}$ and Pt-based electrocatalysts in the presence of methanol is caused by the adsorption of methanol molecules on the active sites for ORR. In contrast, the ORR half-wave and onset potentials of $\mathrm{PdCu}_{3}$ and PdFeIr are not significantly affected by the presence of methanol $[95,109]$. These results indicate that Pd-based compounds are potential electrocatalysts for DMFCs.

\subsection{Pt-Decorated Pd and Pd Bimetallic Alloy Catalysts for ORR Electrocatalysts in Acidic Media}

Recently, several efforts have been made to develop Pd-based ORR electrocatalysts with small amounts of Pt. The MA of Pt towards ORR can be improved by coating with $\mathrm{Pt}$, as electrocatalytic reactions proceed on the surface of electrocatalysts. In particular, electrocatalysts with a Pd@Pt structure are both cost-effective and highly efficient. Wang and coworkers demonstrated that the ORR activity of Pd@Pt catalysts strongly depends on the Pt-Pt distance on monolayer Pt on various single crystal surfaces, which is measured by the extended X-ray absorption fine structure [110]. They obtained a linear relationship between the lattice strain and the ORR activity of the catalysts. These results can be helpful for preparing highly active core-shell-type ORR electrocatalysts with short Pt-Pt distances. Xia and coworkers investigated the relationship between the ORR activity and thickness of Pt-shell-Pd nanocrystals [111]. The Pd@Pt ${ }_{n}$ shell ( $n=1-6$ layers)-type structure can enhance the electrocatalytic activity and durability during ORR in terms of the specific activity. A volcano-shaped relationship was obtained between the ORR specific activity and the number of $\mathrm{Pt}$ layers of the catalysts. Among all the $\mathrm{Pd} @ \mathrm{Pt}_{n}$ catalysts, the $\mathrm{Pd} @ \mathrm{Pt}_{2}$ layer showed the best ORR specific activity (even better than that of Pt). According to the DFT calculations, the enhanced ORR specific

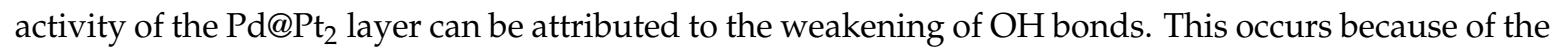
ligand and strain effects, which increase the rate of $\mathrm{OH}$ hydrogenation. The experimental results were consistent with those obtained computationally. These results suggest that Pd@Pt electrocatalysts show better performance than carbon-supported Pt. The Pd@Pt structure is promising for achieving the US Department of Energy specifications, which are as follows: A lifetime of $5000 \mathrm{~h}$, a mass activity over $0.44 \mathrm{~A} \mathrm{mg}^{-1}$ (per platinum group metal) and $10.1 \mathrm{~A} \$^{-1}$ [112]. Indeed, the Adzic group has reported that the electrocatalytic activities, normalized by the price of Pt group metals, of Pd@Pt-type structures can surpass the standards specified by the US Department of Energy [113]. Various efforts have been made to modify the Pt-Pt distance and electronic state of the surface of Pd-based compounds in Pd $(\mathrm{Pd}-\mathrm{M}) @ \mathrm{Pt}$ shell electrocatalysts (Table 4).

Table 4. MA and specific activity (SA) at $0.9 \mathrm{~V}$ versus RHE for the ORR of various Pd or Pd-based core-Pt shell catalysts in an $\mathrm{O}_{2}$-saturated $0.1 \mathrm{M} \mathrm{HClO}_{4}$ aqueous solution.

\begin{tabular}{|c|c|c|c|}
\hline Catalyst & $\mathrm{MA}$ at $0.90 \mathrm{~V} / \mathrm{A} \mathrm{mg}{ }^{-1} \mathrm{Pt}$ & $\mathrm{SA}$ at $0.90 \mathrm{~V} / \mathrm{A} \mathrm{m}^{-2}$ & Ref \\
\hline Pt & $0.20-0.23$ & $0.23-0.31$ & [89-91] \\
\hline Pd@Pt & $0.34,0.8$ & - & {$[111,114]$} \\
\hline $\mathrm{Pd}_{\mathrm{NR}} @ \mathrm{Pt}_{\mathrm{ML}}$ & 1.81 & 0.93 & [115] \\
\hline $\mathrm{Au}_{60} \mathrm{Pd}_{40} @ \mathrm{Pt}$ & 1.82 & 2.2 & [116] \\
\hline Pt-enriched nanocage & 1.12 & 2.48 & [117] \\
\hline $\begin{array}{c}\text { Pd@Pt concave } \\
\text { decahedra }\end{array}$ & 1.60 & 1.66 & [118] \\
\hline $\mathrm{Pd}_{8} \mathrm{CoZn} @ \mathrm{Pt}$ & 2.62 & 4.76 & {$[96]$} \\
\hline $\mathrm{Pd}_{42} \mathrm{Fe}_{58} @ \mathrm{Pt}$ & 2.8 & - & [119] \\
\hline Pd@PtNi & 2.5 & 2.7 & [120] \\
\hline $\mathrm{Pd} @ \mathrm{Pt}_{3} \mathrm{Ni}(\mathrm{Pt}-\mathrm{skin})$ & 16.7 & 14.2 & [121] \\
\hline
\end{tabular}


Abruña et al. and Wang et al. prepared electrocatalysts with a Pt-decorated Pd-M@Pd core-shell-type structure by the spontaneous displacement of Pd with Pt. This structure improved the MA of the catalysts by more than 10 times $[9,119]$. The deposition of Pt on Pd and Pd-based compounds in order to create core-shell structures is strongly affected by particle size and the secondary materials used, such as Fe [119]. Markovic and coworkers demonstrated that in acidic media, the specific activity towards ORR of $\mathrm{Pt}$ (111) is more than two times higher than that of $\mathrm{Pt}(100)$ [122]. Moreover, Xia and coworkers also showed that Pt octahedral nanocages having Pt (111) facets have a higher activity towards ORR than Pt cubic nanocages with (100) facets, indicating that Pt nanostructures with (111) facets show good ORR electrocatalytic activity [102]. However, no significant improvement is observed in the ORR activity of $\mathrm{Pd}$ nanostructures upon the incorporation of $\mathrm{Pt}$ (111) facets [123].

$\mathrm{Li}$ and coworkers developed ultra-thin icosahedral Pt-enriched nanocages through the selective removal of icosahedral Pd from Pd@Pt using a nitric acid solution [117], as shown in Figure 10. Among the nanocages with low-index facets, the icosahedral Pt-enriched nanocages with $\mathrm{Pt}$ (111) facets showed the highest electrocatalytic activity towards ORR. The as-prepared Pt-enriched nanocages showed between 7 and 10 times higher MA and specific activity, respectively, than JM Pt/C.
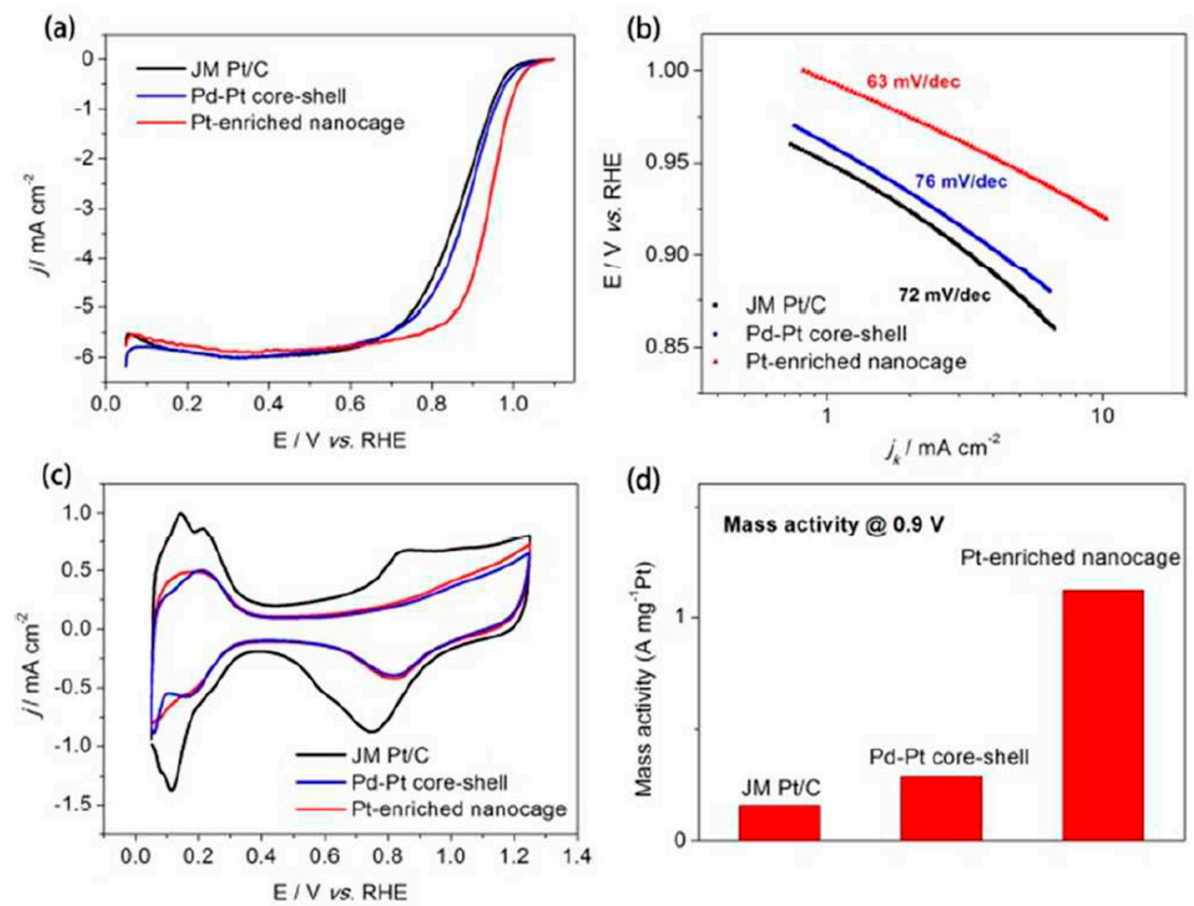

Figure 10. (a) Linear sweep voltammograms for ORR over Pt nanoparticles, core-shell Pd-Pt and Pt-enriched nanocages in an $\mathrm{O}_{2}$-saturated $0.1 \mathrm{M} \mathrm{HClO}_{4}$ solution with a sweep rate of $10 \mathrm{mV} \mathrm{s}^{-1}$ and (b) the corresponding Tafel plots. (c) Cyclic voltammetry curves in an $\mathrm{N}_{2}$-saturated $0.1 \mathrm{M} \mathrm{HClO}_{4}$ solution with a sweep rate of $10 \mathrm{mV} \mathrm{s}^{-1}$ and (d) the MA for these three catalysts at $0.9 \mathrm{~V}$ versus RHE. Reproduced with permission [117]. Copyright 2016, American Chemical Society.

Recently, it has been reported that Pt-decorated ternary nanoparticles show enhanced ORR activity [96]. Wang and coworkers prepared ternary $\operatorname{Pd}_{x} \operatorname{CoZn}(x=0,4,8$ and 12) and Pt-decorated $\mathrm{Pd}_{8} \mathrm{CoZn}$ and evaluated their electrocatalytic activity and durability for ORR. They showed that a composition of Pd:Co:Zn = 8:1:1 was optimum for enhanced ORR activity. The ORR MA of Pt-coated $\mathrm{Pd}_{8} \mathrm{CoZn}$ nanoparticles at $0.9 \mathrm{~V}$ was about 27 times higher than that of the commercially available $\mathrm{Pt} / \mathrm{C}$. This approach can be helpful for the development of Pt-coated Pd-based ternary catalysts with a large number of active sites for ORR.

The use of Pd core materials in electrocatalysts can surpass conventional Pt-based electrocatalysts. Among the Pt-based electrocatalysts for ORR, the Pt-Ni bimetallic electrocatalyst is the best choice. For example, Stamenkovic et al. reported that the mass activity at $0.9 \mathrm{~V}$ versus RHE of 
a $\mathrm{PtNi}_{3}$ nanoframe is $5.7 \mathrm{~A} \mathrm{mg}^{-1} \mathrm{Pt}$, much higher than that of state-of-the-art Pt nanoparticles [124]. Moreover, the electrocatalytic activity of $\mathrm{Pt}_{3} \mathrm{Ni}$ is significantly improved by transition metal doping. In particular, Mo-doped $\mathrm{Pt}_{3} \mathrm{Ni}$ showed the best ORR electrocatalytic activity at that time (mass

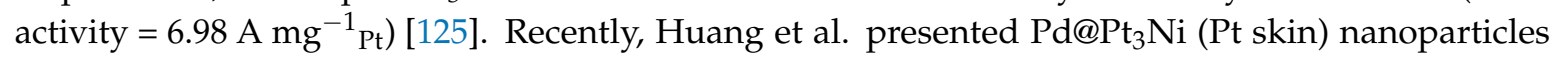
(mass activity $=14.2 \mathrm{~A} \mathrm{mg}^{-1} \mathrm{Pt}$ ), which exhibited the highest electrocatalytic activity towards ORR ever recorded, more than those of state-of-the-art Pt-Ni catalysts [121].

\section{Conclusions}

Electrocatalysts developed over recent years can be classified into three categories: (1) Pd-based materials for formic acid oxidation, (2) Pd-based materials for ORR, and (3) Pd-core-Pt shell-structured catalysts. Various advances made in the development of electronically modified and morphology-controlled Pd-based electrocatalysts for formic acid oxidation have been discussed in this review. Secondary materials such as $\mathrm{Co}, \mathrm{Ni}, \mathrm{Cu}, \mathrm{Pt}$ and $\mathrm{Au}$ play an important role in the modification of the electronic states (i.e., tuning the d-band center) of Pd-based electrocatalysts. The formic acid oxidation activity of these catalysts depends on the downshift of the $\mathrm{CO}$ oxidation voltage. However, since $\mathrm{HCOO}_{\mathrm{ad}}$ should be formed on Pd sites in the initial stage of formic acid oxidation, the catalyst should have an optimum d-band center value for high electrocatalytic activity. The d-band center value can be tuned by the formation of Pd-based ternary materials. Electrochemical dealloying is an effective approach to prepare electrocatalysts with high activities. For example, electrochemically treated intermetallic $\mathrm{Pd}_{3} \mathrm{~Pb}$ exhibits a significantly higher electrocatalytic activity than $\mathrm{Pd} N \mathrm{NP} / \mathrm{CB}$.

Since Pd shows physicochemical characteristics similar to those of $\mathrm{Pt}$ and a higher methanol tolerance than Pt, Pd-based materials are potential catalysts for ORR under acidic conditions. Although $\mathrm{Pd}-\mathrm{Cu}$ bimetallic compounds with electrocatalytic activity higher than that of Pt have not been realized experimentally yet, theoretical calculations have shown that Pd-based compounds are promising electrocatalysts. DFT calculations have revealed that the adsorption energy of dissociate $\mathrm{O}$ on Pd-based electrocatalysts is similar to that of Pt. Further investigation of Pd-based bimetallic catalysts for ORR is necessary. Although, the low stability of Pd during ORR under acidic conditions limits their application for PEFCs. Only a trace amount of $\mathrm{Au}$ is required to improve the ORR durability of Pd-based electrocatalysts. Intermetallic $\mathrm{Pd}_{3} \mathrm{~Pb}$ has enhanced ORR activity in alkaline media when compared with pure Pd and Pt. Pt-based materials have realized activities higher than $10 \mathrm{~A} \mathrm{mg}^{-1} \mathrm{Pt}$ under acidic conditions, based on their mass activity. In contrast, the mass activities towards ORR in alkaline media remain less than $1 \mathrm{~A} \mathrm{mg}^{-1} \mathrm{Pd}$ when Pd-based materials are used as electrocatalysts. No published work has provided answers to the following two important questions: (i) Why can Pd-based materials with higher ORR activities than Pt-based materials under acidic conditions not be developed, although theoretical studies exhibit that Pd-based materials are promising electrocatalysts? Secondly, what is the key factor for improving the electrocatalytic activity towards ORR in alkaline media (i.e., why does the pure Pd electrocatalyst have almost the same activity as pure Pt towards ORR in alkaline media, despite $\mathrm{Pd}$ having a significantly higher $\mathrm{d}$-band center and $\mathrm{O}$ adsorption energy than $\mathrm{Pt}$ )? Extensive research efforts, both experimental and theoretical, are required to answer these questions. We believe that these results will accelerate the development of novel electrocatalysts.

Funding: This research was funded by JSPS KAKENHI grant number 16K05945.

Conflicts of Interest: The authors declare no conflict of interest.

\section{References}

1. Ahmadi, T.S.; Wang, Z.L.; Green, T.C.; Henglein El-Sayed, A.M. Shape-Controlled Synthesis of Colloidal Platinum Nanoparticles. Science 1996, 272, 1924-1925. [CrossRef] [PubMed]

2. Yu, X.; Pickup, P.G. Recent advances in direct formic acid fuel cells (DFAFC). J. Power Sources 2008, 182, 124-132. [CrossRef] 
3. Demirci, U.B. Direct liquid-feed fuel cells: Thermodynamic and environmental concerns. J. Power Sources 2007, 169, 239-246. [CrossRef]

4. Rice, C.; Ha, S.; Masel, R.I.; Waszczuk, P.; Wieckowski, A.; Barnard, T. Direct formic acid fuel cells. J. Power Sources 2002, 111, 83-89. [CrossRef]

5. Raj, C.R.; Samanta, A.; Noh, S.H.; Mondal, S.; Okajima, T.; Ohsaka, T. Emerging new generation electrocatalysts for the oxygen reduction reaction. J. Mater. Chem. A 2016, 4, 11156-11178. [CrossRef]

6. Chen, A.; Ostrom, C. Palladium-Based Nanomaterials: Synthesis and Electrochemical Applications. Chem. Rev. 2015, 115, 11999-12044. [CrossRef] [PubMed]

7. Zhang, L.; Lee, K.; Zhang, J. The effect of heat treatment on nanoparticle size and ORR activity for carbon-supported Pd-Co alloy electrocatalysts. Electrochim. Acta 2007, 52, 3088-3094. [CrossRef]

8. Shi, Q.; Zhu, C.; Bi, C.; Xi, H.; Engelhard, H.M.; Du, D.; Lin, Y. Intermetallic $\mathrm{Pd}_{3} \mathrm{~Pb}$ nanowire networks boost ethanol oxidation and oxygen reduction reactions with significantly improved methanol tolerance. J. Mater. Chem. A 2017, 5, 23952-23959. [CrossRef]

9. Wang, D.; Xin, H.L.; Wang, H.; Yu, Y.; Rus, E.; Muller, D.A.; DiSalvo, F.J.; Abruña, H.D. Facile Synthesis of Carbon-Supported Pd-Co Core-Shell Nanoparticles as Oxygen Reduction Electrocatalysts and Their Enhanced Activity and Stability with Monolayer Pt Decoration. Chem. Mater. 2012, 24, 2274-2281. [CrossRef]

10. Stamenkovic, V.R.; Mun, B.S.; Arenz, M.; Mayrhofer, K.J.J.; Lucas, C.A.; Wang, G.; Ross, P.N.; Markovic, N.M. Trends in electrocatalysis on extended and nanoscale Pt-bimetallic alloy surfaces. Nat. Mater. 2007, 6, 241-247. [CrossRef] [PubMed]

11. Greeley, J.; Stephens, I.E.L.; Bondarenko, A.S.; Johansson, T.P.; Hansen, H.A.; Jaramillo, T.F.; Rossmeisl, J.; Chorkendorff, I.; Nørskov, J.K. Alloys of platinum and early transition metals as oxygen reduction electrocatalysts. Nat. Chem. 2009, 1, 552-556. [CrossRef] [PubMed]

12. Shao, M.; Chang, Q.; Dodelet, J.-P.; Chenitz, R. Recent Advances in Electrocatalysts for Oxygen Reduction Reaction. Chem. Rev. 2016, 116, 3594-3657. [CrossRef] [PubMed]

13. Wang, Y.; Zou, S.; Cai, W.-B. Recent Advances on Electro-Oxidation of Ethanol on Pt- and Pd-Based Catalysts: From Reaction Mechanisms to Catalytic Materials. Catalysts 2015, 5, 1507-1534. [CrossRef]

14. Antolini, E. Alloy vs. intermetallic compounds: Effect of the ordering on the electrocatalytic activity for oxygen reduction and the stability of low temperature fuel cell catalysts. Appl. Catal. B Environ. 2017, 217, 201-213. [CrossRef]

15. Erikson, H.; Sarapuu, A.; Gullón, J.S.; Tammeveski, K. Recent progress in oxygen reduction electrocatalysis on Pd-based catalysts. J. Electroanal. Chem. 2016, 780, 327-336. [CrossRef]

16. Bianchini, C.; Shen, P.K. Palladium-Based Electrocatalysts for Alcohol Oxidation in Half Cells and in Direct Alcohol Fuel Cells. Chem. Rev. 2009, 109, 4183-4206. [CrossRef] [PubMed]

17. Yin, Z.; Lin, L.; Ma, D. Construction of Pd-based nano-catalysts for fuel cells: Opportunities and challenges. Catal. Sci. Technol. 2014, 4, 4116-4128. [CrossRef]

18. Gómez, J.C.C.; Moliner, R.; Lázaro, M.J. Palladium-Based Catalysts as Electrodes for Direct Methanol Fuel Cells: A Last Ten Years Review. Catalysts 2016, 6, 130. [CrossRef]

19. Meng, H.; Zeng, D.; Xie, F. Recent Development of Pd-Based Electrocatalysts for Proton Exchange Membrane Fuel Cells. Catalysts 2015, 5, 1221-1274. [CrossRef]

20. Antolini, E. Structural parameters of supported fuel cell catalysts: The effect of particle size, inter-particle distance and metal loading on catalytic activity and fuel cell performance. Appl. Catal. B Environ. 2016, 181, 298-313. [CrossRef]

21. Halseid, M.C.; Jusys, Z.; Behm, R.J. Ethanol Oxidation over a Pt/C Catalyst at High emperatures and Pressure: An Online Electrochemical Mass Spectrometry Study. J. Phys. Chem. C 2010, 114, 22573-22581. [CrossRef]

22. Bagotzky, V.S.; Vassiliev, Y.B.; Khazova, O.A.J. Generalized scheme of chemisorption, electrooxidation and electroreduction of simple organic compounds on platinum group metals. Electroanal. Chem. 1977, 81, 229. [CrossRef]

23. Iwasita, T.; Hoster, H.; Anacker, A.J.; Lin, W.F.; Vielstich, W. Methanol Oxidation on PtRu Electrodes. Influence of Surface Structure and Pt-Ru Atom Distribution. Langmuir 2000, 16, 522-529. [CrossRef]

24. Kodiyath, R.; Ramesh, G.V.; Koudelkova, E.; Tanabe, T.; Ito, M.; Manikandan, M.; Ueda, S.; Fujita, T.; Umezawa, N.; Noguchi, H.; et al. Promoted C-C bond cleavage over intermetallic $\mathrm{TaPt}_{3}$ catalyst toward low-temperature energy extraction from ethanol. Energy Environ. Sci. 2015, 8, 1685-1689. [CrossRef] 
25. Kunimatsu, K.; Kita, H. Infrared spectroscopic study of methanol and formic acid absorbates on a platinum electrode: Part II. Role of the linear $\mathrm{CO}(\mathrm{a})$ derived from methanol and formic acid in the electrocatalytic oxidation of $\mathrm{CH}_{3} \mathrm{OH}$ and HCOOH. Electroanal. Chem. 1987, 218, 155. [CrossRef]

26. Corrigan, D.S.; Weaver, M.J. Mechanisms of formic acid, methanol, and carbon monoxide electrooxidation at platinum as examined by single potential alteration infrared spectroscopy. J. Electroanal. Chem. 1988, 241, 143. [CrossRef]

27. Gao, W.; Mueller, J.E.; Jiang, Q.; Jacob, T. The Role of Co-Adsorbed CO and OH in the Electrooxidation of Formic Acid on Pt(111). Angew. Chem. Int. Ed. 2012, 51, 9448. [CrossRef]

28. Chen, Y.-X.; Heinen, M.; Jusys, Z.; Behm, R.J. Bridge-Bonded Formate: Active Intermediate or Spectator Species in Formic Acid Oxidation on a Pt Film Electrode? Langmuir 2006, 22, 10399-10408. [CrossRef] [PubMed]

29. Gao, W.; Keith, J.A.; Anton, J.; Jacob, T. Theoretical Elucidation of the Competitive Electro-oxidation Mechanisms of Formic Acid on Pt(111). J. Am. Chem. Soc. 2010, 132, 18377-18385. [CrossRef] [PubMed]

30. Gao, W.; Keith, J.A.; Anton, J.; Jacob, T. Oxidation of formic acid on the Pt(111) surface in the gas phase. Dalton Trans. 2010, 39, 8450-8456. [CrossRef] [PubMed]

31. Gunji, T.; Noh, S.H.; Tanabe, T.; Han, B.; Nien, C.Y.; Ohsaka, T.; Matsumoto, F. Enhanced Electrocatalytic Activity of Carbon-Supported Ordered Intermetallic Palladium-Lead $\left(\mathrm{Pd}_{3} \mathrm{~Pb}\right)$ Nanoparticles toward Electrooxidation of Formic Acid. Chem. Mater. 2017, 29, 2906-2913. [CrossRef]

32. Zhang, S.; Shao, Y.Y.; Liao, H.G.; Liu, J.; Aksay, I.A.; Yin, G.P.; Lin, Y.H. Graphene Decorated with PtAu Alloy Nanoparticles: Facile Synthesis and Promising Application for Formic Acid Oxidation. Chem. Mater. 2011, 23, 1079-1081. [CrossRef]

33. Roychowdhury, C.; Matsumoto, F.; Mutolo, P.F.; Abruña, H.D.; DiSalvo, F.J. Synthesis and characterization and electrochemical activity of PtBi nanoparticles prepared by the polyol process. Chem. Mater. 2005, 17, 5871-5876. [CrossRef]

34. Roychowdhury, C.; Matsumoto, F.; Zeldovich, V.B.; Warren, S.C.; Mutolo, P.F.; Ballesteros, M.; Wiesner, U.; Abruña, H.D.; DiSalvo, F. Synthesis, Characterization and Electrocatalytic activity of PtBi and PtPb Nanoparticles prepared by Borohydride reduction in Methanol. Chem. Mater. 2006, 18, 3365-3372. [CrossRef]

35. Matsumoto, F.; Roychowdhury, C.; DiSalvo, F.J.; Abruña, H.D. Electrochemical Activity of Ordered Intermetallic $\mathrm{PtPb}$ Nanoparticles Prepared by Borohydride Reduction towards Formic Acid Oxidation for Fuel Cell Applications. J. Electrochem. Soc. 2008, 155, B148-B154. [CrossRef]

36. Wang, H.S.; Alden, L.; DiSalvo, F.J.; Abruña, H.D. Electrocatalytic mechanism and kinetics of SOMs oxidation on ordered PtPb and PtBi intermetallic compounds: DEMS and FTIRS study. Phys. Chem. Chem. Phys. 2008, 10, 3739-3751. [CrossRef] [PubMed]

37. Matsumoto, F. Ethanol and Methanol Oxidation Activity of $\mathrm{PtPb}, \mathrm{PtBi}$, and $\mathrm{PtBi}_{2}$ Intermetallic Compounds in Alkaline Media. Electrochemistry 2012, 80, 132-138. [CrossRef]

38. Capon, A.; Parsons, R.J. The oxidation of formic acid on noble metal electrodes: II. A comparison of the behaviour of pure electrodes. J. Electroanal. Chem. Interfacial Electrochem. 1973, 44, 239-254. [CrossRef]

39. Zhang, H.-X.; Wang, C.; Wang, J.-Y.; Zhai, J.-J.; Cai, W.-B. Carbon-Supported Pd-Pt Nanoalloy with Low Pt Content and Superior Catalysis for Formic Acid Electro-oxidation. J. Phys. Chem. C 2010, 114, 6446-6451. [CrossRef]

40. Elnabawy, A.O.; Herron, J.A.; Scaranto, J.; Mavrikakis, M. Structure Sensitivity of Formic Acid Electrooxidation on Transition Metal Surfaces: A First-Principles Study. J. Electrochem. Soc. 2018, 165, J3109-J3121. [CrossRef]

41. Scaranto, J.; Mavrikakis, M. Density functional theory studies of HCOOH decomposition on Pd(111). Surf. Sci. 2016, 650, 111-120. [CrossRef]

42. Melchionna, M.; Bracamonte, M.V.; Giuliani, A.; Nasi, L.; Montini, T.; Tavagnacco, C.; Bonchio, M.; Fornasiero, P.; Prato, M. Pd@ $\mathrm{TiO}_{2}$ /carbon nanohorn electrocatalysts: Reversible $\mathrm{CO}_{2}$ hydrogenation to formic acid. Energy Environ. Sci. 2018, 11, 1571-1580. [CrossRef]

43. Jiang, K.; Zhang, H.X.; Zou, S.; Cai, W.B. Electrocatalysis of formic acid on palladium and platinum surfaces: From fundamental mechanisms to fuel cell applications. Phys. Chem. Chem. Phys. 2014, 16, 20360-20376. [CrossRef] [PubMed] 
44. Zhang, H.-X.; Wang, S.-H.; Jiang, K.; André, T.; Cai, W.-B. In Situ Spectroscopic Investigation of CO Accumulation and Poisoning on Pd Black Surfaces in Concentrated HCOOH. J. Power Sources 2012, 199, 165-169. [CrossRef]

45. Wang, J.-Y.; Zhang, H.-X.; Jiang, K.; Cai, W.-B. From HCOOH to CO at Pd Electrodes: A Surface-Enhanced Infrared Spectroscopy Study. J. Am. Chem. Soc. 2011, 133, 14876-14879. [CrossRef] [PubMed]

46. Xi, Z.; Erdosy, D.P.; Mendoza-Garcia, A.; Duchesne, P.N.; Li, J.; Muzzio, M.; Li, Q.; Zhang, P.; Sun, S. Pd Nanoparticles Coupled to $\mathrm{WO}_{2.72}$ Nanorods for Enhanced Electrochemical Oxidation of Formic Acid. Nano Lett. 2017, 17, 2727-2731. [CrossRef] [PubMed]

47. Mazumder, V.; Chi, M.; Mankin, M.; Liu, Y.; Metin, O.; Sun, D.; More, K.L.; Sun, S. A Facile Synthesis of MPd $(\mathrm{M}=\mathrm{Co}, \mathrm{Cu})$ Nanoparticles and Their Catalysis for Formic Acid Oxidation. Nano Lett. 2012, 12, 1102-1106. [CrossRef] [PubMed]

48. Du, C.Y.; Chen, M.; Wang, W.G.; Yin, G.P. Nanoporous PdNi Alloy Nanowires as Highly Active Catalysts for the Electro-Oxidation of Formic Acid. ACS Appl. Mater. Interfaces 2011, 3, 105-109. [CrossRef] [PubMed]

49. Hu, S.Z.; Munoz, F.; Noborikawa, J.; Haan, J.; Scudiero, L.; Ha, S. Carbon Supported Pd-Based Bimetallic and Trimetallic Catalyst for Formic Acid Electrochemical Oxidation. Appl. Catal. B 2016, 180, 758-765. [CrossRef]

50. Chen, D.; Sun, P.; Liu, H.; Yang, J. Bimetallic Cu-Pd alloy multipods and their highly electrocatalytic performance for formic acid oxidation and oxygen reduction. J. Mater. Chem. A 2017, 5, 4421-4429. [CrossRef]

51. Feng, L.; Sun, X.; Liu, C.; Xing, W. Poisoning effect diminished on a novel $\mathrm{PdHoO}_{x} / \mathrm{C}$ catalyst for the electrooxidation of formic acid. Chem. Commun. 2012, 48, 419-421. [CrossRef] [PubMed]

52. Abe, H.; Yoshikawa, H.; Umezawa, N.; Xu, Y.; Saravanan, G.; Ramesh, G.V.; Tanabe, T.; Kodiyath, R.; Ueda, S.; Sekido, N.; et al. Correlation between the surface electronic structure and CO-oxidation activity of Pt alloys. Phys. Chem. Chem. Phys. 2015, 17, 4879-4887. [CrossRef] [PubMed]

53. Zhou, W.J.; Lee, J.Y. Highly active core-shell Au@Pd catalyst for formic acid electrooxidation. Electrochem. Commun. 2007, 9, 1725-1729. [CrossRef]

54. Liu, P.; Norskov, J.K. Ligand and ensemble effects in adsorption on alloy surfaces. Phys. Chem. Chem. Phys. 2001, 3, 3814-3818. [CrossRef]

55. Yin, X.; Chen, Q.; Tian, P.; Zhang, P.; Zhang, Z.; Voyles, P.M.; Wang, X. Ionic Layer Epitaxy of Nanometer-Thick Palladium Nanosheets with Enhanced Electrocatalytic Properties. Chem. Mater. 2018, 30, 3308. [CrossRef]

56. He, N.; Gong, Y.; Yang, Y. ScienceDirect an effective Pd@Ni-B/C anode catalyst for electro- oxidation of formic acid. Int. J. Hydrogen Energy 2018, 43, 3216-3222. [CrossRef]

57. Huang, L.; Yang, J.; Wu, M.; Shi, Z.Q.; Lin, Z.; Kang, X.W.; Chen, S.W. PdAg@Pd core-shell nanotubes: Superior catalytic performance towards electrochemical oxidation of formic acid and methanol. J. Power Sources 2018, 398, 201-208. [CrossRef]

58. Zhang, W.; Huang, H.; Li, F.; Deng, K.; Wang, X. Palladium nanoparticles supported on graphitic carbon nitride-modified reduced graphene oxide as highly efficient catalysts for formic acid and methanol electrooxidation. J. Mater. Chem. A 2014, 2, 19084-19094. [CrossRef]

59. Cui, Z.; Yang, M.; DiSalvo, F.J. Mesoporous $\mathrm{Ti}_{0.5} \mathrm{Cr}_{0.5} \mathrm{~N}$ Supported PdAg Nanoalloy as Highly Active and Stable Catalysts for the Electro-Oxidation of Formic Acid and Methanol. ACS Nano 2014, 8, 6106-6113. [CrossRef] [PubMed]

60. Hua, S.; Scudiero, L.; Ha, S. Effect of Au and Ru in Au@Pd and Ru@Pd Core@Shell Nanoparticles for Direct Formic Acid Fuel Cells. ECS Trans. 2014, 64, 1121-1127. [CrossRef]

61. Stamenkovic, V.R.; Fowler, B.; Mun, B.S.; Wang, G.; Ross, P.N.; Lucas, C.A.; Markovic, N.M. Improved Oxygen Reduction Activity on $\mathrm{Pt}_{3} \mathrm{Ni}(111)$ via Increased Surface Site Availability. Science 2007, 315, $493-497$. [CrossRef] [PubMed]

62. Hodnik, N.; Jeyabharathi, C.; Meier, J.C.; Kostka, A.; Phani, K.L.; Recnik, A.; Bele, M.; Hocevar, S.; Gaberscek, M.; Mayrhofer, K.J.J. Effect of ordering of $\mathrm{PtCu}_{3}$ nanoparticle structure on the activity and stability for the oxygen reduction reaction. Phys. Chem. Chem. Phys. 2014, 16, 13610-13615. [CrossRef] [PubMed]

63. Wang, D.; Yu, Y.; Xin, H.L.; Hovden, R.; Ercius, P.; Mundy, J.A.; Chen, H.; Richard, J.H.; Muller, D.A.; DiSalvo, F.J. Tuning Oxygen Reduction Reaction Activity Via Controllable Dealloying: A Model Study of Ordered $\mathrm{Cu}_{3} \mathrm{Pt} / \mathrm{C}$ Intermetallic Nanocatalysts. Nano Lett. 2012, 12, 5230-5238. [CrossRef] [PubMed]

64. Abe, H.; Matsumoto, F.; Alden, L.R.; Warren, S.C.; Abruña, H.D.; DiSalvo, F.J. High Electrocatalytic Activity of Atomically Ordered $\mathrm{Pt}_{3}$ Ti Nanoparticles. J. Am. Chem. Soc. 2008, 130, 5452-5458. [CrossRef] [PubMed] 
65. De-los-Santos-Alvarez, N.; Alden, L.R.; Rus, E.; Wang, H.; DiSalvo, F.J.; Abruña, H.D. CO tolerance of ordered intermetallic phases. J. Electroanal. Chem. 2009, 626, 14-22. [CrossRef]

66. Shao, Y.Y.; Zhang, S.; Wang, C.M.; Nie, Z.M.; Liu, J.; Wang, Y.; Lin, Y.H. Highly durable graphene nanoplatelets supported Pt nanocatalysts for oxygen reduction. J. Power Sources 2010, 195, 4600-4605. [CrossRef]

67. Fu, K.; Wang, Y.; Mao, L.; Jin, J.; Yang, S.; Li, G. Facile one-pot synthesis of graphene-porous carbon nanofibers hybrid support for Pt nanoparticles with high activity towards oxygen reduction. Electrochim. Acta 2016, 215, 427-434. [CrossRef]

68. Nassr, A.B.A.A.; Quetschke, A.; Koslowski, E.; Bron, M. Electrocatalytic Oxidation of Formic Acid on Pd/MWCNTs Nanocatalysts Prepared by the Polyol Method. Electrochim. Acta 2013, 102, 202-211. [CrossRef]

69. Mondal, S.L.; Ghosh, S.; Raj, C.R. Unzipping of Single-Walled Carbon Nanotube for the Development of Electrocatalytically Active Hybrid Catalyst of Graphitic Carbon and Pd Nanoparticles. ACS Omega 2018, 3, 622-630. [CrossRef]

70. Hammer, B.; Nørskov, J.K. Theoretical surface science and catalysis-Calculations and concepts. Adv. Catal. 2000, 45, 71-129.

71. Stamenkovic, V.; Mun, B.S.; Mayrhofer, K.J.J.; Ross, P.N.; Markovic, N.M.; Rossmeisl, J.; Greeley, J.; Norskov, J.K. Changing the Activity of Electrocatalysts for Oxygen Reduction by Tuning the Surface Electronic Structure. Angew. Chem. Int. Ed. 2006, 45, 2897-2906. [CrossRef] [PubMed]

72. Wang, J.X.; Zhang, J.L.; Adzic, R.R. Catalytic Activity-d-Band Center Correlation for the $\mathrm{O}_{2}$ Reduction Reaction on Platinum in Alkaline Solutions. J. Phys. Chem. A 2007, 111, 12702-12710. [CrossRef] [PubMed]

73. Gunji, T.; Wakabayashi, R.H.; Noh, S.H.; Han, B.; Matsumoto, F.; DiSalvo, F.J.; Abruña, H.D. The effect of alloying of transition metals $(\mathrm{M}=\mathrm{Fe}, \mathrm{Co}, \mathrm{Ni})$ with palladium catalysts on the electrocatalytic activity for the oxygen reduction reaction in alkaline media. Electrochim. Acta 2018, 283, 1045-1052. [CrossRef]

74. Cui, Z.M.; Chen, H.; Zhao, M.; DiSalvo, F.J. High Performance $\mathrm{Pd}_{3} \mathrm{~Pb}$ Intermetallic Catalyst for Electrochemical Oxygen Reduction. Nano Lett. 2016, 16, 2560-2566. [CrossRef] [PubMed]

75. Bu, L.Z.; Shao, Q.; Pi, Y.C.; Yao, J.L.; Luo, M.C.; Lang, J.P.; Hwang, S.; Xin, H.L.; Huang, B.L.; Guo, J.; et al. Coupled s-p-d Exchange in Facet-Controlled $\mathrm{Pd}_{3} \mathrm{~Pb}$ Tripods Enhances Oxygen Reduction. Catal. Chem. 2018, 4, 359-371. [CrossRef]

76. Luo, S.; Tang, M.; Wu, X.; Ou, Y.; Wang, Z.; Jian, N.; Li, X.; Lin, Y.; Yan, Y.; Huang, J.; et al. Intermetallic $\mathrm{Pd}_{3} \mathrm{~Pb}$ square nanoplates as highly efficient electrocatalysts for oxygen reduction reaction. CrystEngComm 2019, Advance Article. [CrossRef]

77. Wang, K.; Qin, Y.; Lv, F.; Li, M.; Liu, Q.; Lin, F.; Feng, J. Intermetallic $\mathrm{Pd}_{3} \mathrm{~Pb}$ nanoplates enhance oxygen reduction catalysis with excellent methanol tolerance. Small 2018, 1700331, 1-8.

78. Liu, S.; Wang, Y.; Liu, L.; Li, M.; Lv, W.; Zhao, X.; Qin, Z.; Zhu, P.; Wang, G.; Long, Z.; et al. One-Pot Synthesis of Pd@PtNi Core-shell Nanoflowers Supported on the Multi-Walled Carbon Nanotubes with Boosting Activity toward Oxygen Reduction in Alkaline Electrolyte. J. Power Sources 2017, 365, 26-33. [CrossRef]

79. Lu, Y.; Jiang, Y.; Gao, X.; Wang, X.; Chen, W. Strongly Coupled Pd anotetrahedron/Tungsten Oxide Nanosheet Hybrids with Enhanced Catalytic Activity and Stability as Oxygen Reduction Electrocatalysts. J. Am. Chem. Soc. 2014, 136, 11687-11697. [CrossRef] [PubMed]

80. Wang, M.; Qin, X.; Jiang, K.; Dong, Y.; Shao, M.; Cai, W.-B. Electrocatalytic Activities of Oxygen Reduction Reaction on Pd/C and Pd-B/C Catalysts. J. Phys. Chem. C 2017, 121, 3416-3423. [CrossRef]

81. Xue, Q.; Bai, J.; Han, C.; Chen, P.; Jiang, J.-X.; Chen, Y. Au Nanowires@Pd-Polyethylenimine Nanohybrids as Highly Active and Methanol-Tolerant Electrocatalysts toward Oxygen Reduction Reaction in Alkaline Media. ACS Catal. 2018, 8, 11287-11295. [CrossRef]

82. Cui, Z.; Li, L.; Manthiram, A.; Goodenough, J.B. Enhanced Cycling Stability of Hybrid Li-Air Batteries Enabled by Ordered $\mathrm{Pd}_{3}$ Fe Intermetallic Electrocatalyst. J. Am. Chem. Soc. 2015, 137, 7278-7281. [CrossRef] [PubMed]

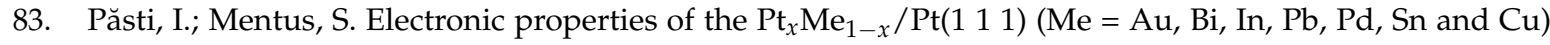
surface alloys: DFT study. Mater. Chem. Phys. 2009, 116, 94-101. [CrossRef]

84. Verdaguer-Casadevall, A.; Hernandez-Fernandez, P.; Stephens, I.E.L.; Chorkendorff, I.; Dahl, S. The effect of ammonia upon the electrocatalysis of hydrogen oxidation and oxygen reduction on polycrystalline platinum. J. Power Sources 2012, 220, 205-210. [CrossRef] 
85. Siahrostami, S.; Verdaguer-Casadevall, A.; Karamad, M.; Deiana, D.; Malacrida, P.; Wickman, B.; Escudero-Escribano, M.; Paoli, E.A.; Frydendal, R.; Hansen, T.W.; et al. Enabling direct $\mathrm{H}_{2} \mathrm{O}_{2}$ production through rational electrocatalyst design. Nat. Mater. 2013, 12, 1137-1143. [CrossRef] [PubMed]

86. Verdaguer-Casadevall, A.; Deiana, D.; Karamad, M.; Siahrostami, S.; Malacrida, P.; Hansen, T.W.; Rossmeisl, J.; Chorkendorff, I.; Stephens, I.E.L. Trends in the Electrochemical Synthesis of $\mathrm{H}_{2} \mathrm{O}_{2}$ : Enhancing Activity and Selectivity by Electrocatalytic Site Engineering. Nano Lett. 2014, 14, 1603-1608. [CrossRef] [PubMed]

87. Jirkovsky, J.S.; Panas, I.; Ahlberg, E.; Halasa, M.; Romani, S.; Schiffrin, D.J. Single Atom Hot-Spots at Au-Pd Nanoalloys for Electrocatalytic $\mathrm{H}_{2} \mathrm{O}_{2}$ Production. J. Am. Chem. Soc. 2011, 133, 19432-19441. [CrossRef] [PubMed]

88. Erikson, H.; Jürmann, G.; Sarapuu, A.; Potter, R.J.; Tammeveski, K. Electroreduction of oxygen on carbon-supported gold catalysts. Electrochim. Acta 2009, 54, 7483-7489. [CrossRef]

89. Gasteiger, H.A.; Kocha, S.S.; Sompalli, B.; Wagner, F.T. Activity Benchmarks and Requirements for Pt, Pt-Alloy, and Non-Pt Oxygen Reduction Catalysts for PEMFCs. Appl. Catal. B 2005, 56, 9-35. [CrossRef]

90. Kim, J.; Lee, S.W.; Carlton, C.; Shao-Horn, Y. Oxygen Reduction Activity of $\mathrm{Pt}_{X} \mathrm{Ni}_{1-X}$ Alloy Nanoparticles on Multiwall Carbon Nanotubes. Electrochem. Solid-State Lett. 2011, 14, B110-B113. [CrossRef]

91. Higuchi, E.; Taguchi, A.; Hayashi, K.; Inoue, H. Electrocatalytic Activity for Oxygen Reduction Reaction of Pt Nanoparticle Catalysts with Narrow Size Distribution Prepared from $\left[\mathrm{Pt}_{3}(\mathrm{Co})_{3}(\mathrm{M}-\mathrm{Co})_{3}\right]_{n}{ }^{2-}(n=3-8)$ Complexes. J. Electroanal. Chem. 2011, 663, 84-89. [CrossRef]

92. Wang, D.; Liu, S.; Wang, J.; Lin, R.; Kawasaki, M.; Rus, E.; Silberstein, K.E.; Lowe, M.A.; Lin, F.; Nordlund, D.; et al. Spontaneous incorporation of gold in palladium-based ternary nanoparticles makes durable electrocatalysts for oxygen reduction reaction. Nat. Commun. 2016, 7, 1-9. [CrossRef] [PubMed]

93. Wang, C.; Chen, D.P.; Sang, X.; Unocic, R.R.; Skrabalak, S.E. Size-Dependent Disorder-Order Transformation in the Synthesis of Monodisperse Intermetallic PdCu Nanocatalysts. ACS Nano 2016, 10, 6345-6353. [CrossRef] [PubMed]

94. Wang, X.P.; Kariuki, N.; Vaughey, J.T.; Goodpaster, J.; Kumar, R.; Myers, D.J. Bimetallic Pd-Cu Oxygen Reduction Electrocatalysts. J. Electrochem. Soc. 2008, 155, B602-B609. [CrossRef]

95. Gunji, T.; Noh, S.H.; Ando, F.; Tanabe, T.; Han, B.; Ohsaka, T.; Matsumoto, F. Electrocatalytic activity of electrochemically dealloyed $\mathrm{PdCu}_{3}$ intermetallic compound towards oxygen reduction reaction in acidic media. J. Mater. Chem. A 2018, 6, 14828. [CrossRef]

96. Xiao, W.; Zhu, J.; Han, L.; Liu, S.; Wang, J.; Wu, Z.; Lei, W.; Xuan, C.; Xin, H.L.; Wang, D. Pt skin on $\mathrm{Pd}-\mathrm{Co}-\mathrm{Zn} / \mathrm{C}$ ternary nanoparticles with enhanced Pt efficiency toward ORR. Nanoscale 2016, 8, 14793-14802. [CrossRef] [PubMed]

97. Duan, H.; Xu, C. Nanoporous PdCr alloys as highly active electrocatalysts for oxygen reduction reaction. Phys. Chem. Chem. Phys. 2016, 18, 4166-4173. [CrossRef] [PubMed]

98. Jiang, G.; Zhu, H.; Zhang, X.; Shen, B.; Wu, L.; Zhang, S.; Lu, G.; Wu, Z.; Sun, S. Core/Shell Face-Centered Tetragonal FePd/Pd Nanoparticles as an Efficient Non-Pt Catalyst for the Oxygen Reduction Reaction. ACS Nano 2015, 9, 11014-11022. [CrossRef] [PubMed]

99. Zuo, Y.; Rao, D.; Li, S.; Li, T.; Zhu, G.; Chen, S.; Song, L.; Chai, Y.; Han, H. Atomic Vacancies Control of Pd-Based Catalysts for Enhanced Electrochemical Performance. Adv. Mater. 2018, 30, 1704171-1704177. [CrossRef] [PubMed]

100. Neergat, M.; Gunasekar, V.; Rahul, R. Carbon-supported Pd-Fe electrocatalysts for oxygen reduction reaction (ORR) and their methanol tolerance. J. Electroanal. Chem. 2011, 658, 25-32. [CrossRef]

101. Shao, M.-H.; Sasaki, K.; Adzic, R.R. Pd-Fe Nanoparticles as Electrocatalysts for Oxygen Reduction. J. Am. Chem. Soc. 2006, 128, 3526-3527. [CrossRef] [PubMed]

102. Ou, L. Design of Pd-Based Bimetallic Catalysts for ORR: A DFT Calculation Study. J. Chem. 2015, 2015, 932616. [CrossRef] [PubMed]

103. Sha, Y.; Yu, T.H.; Merinov, B.V.; Goddard, W.A. DFT Prediction of Oxygen Reduction Reaction on Palladium-Copper Alloy Surfaces. ACS Catal. 2014, 4, 1189-1197. [CrossRef]

104. Noh, S.H.; Kwak, D.H.; Seo, M.H.; Ohsaka, T.; Han, B. First principles study of oxygen reduction reaction mechanisms on $\mathrm{N}$-doped graphene with a transition metal support. Electrochim. Acta 2014, 140, $225-231$. [CrossRef] 
105. Kondo, S.; Nakamura, M.; Maki, N.; Hoshi, N. Active Sites for the Oxygen Reduction Reaction on the Low and High Index Planes of Palladium. J. Phys. Chem. C 2009, 113, 12625-12628. [CrossRef]

106. Meku, E.; Du, C.; Sun, Y.; Du, L.; Wang, Y.; Yin, G. Electrocatalytic Activity and Stability of Ordered Intermetallic Palladium-Iron Nanoparticles toward Oxygen Reduction Reaction. J. Electrochem. Soc. 2016, 163, F132-F138. [CrossRef]

107. Zhao, X.; Takao, S.; Higashi, K.; Kaneko, T.; Samjeskè, G.; Sekizawa, O.; Sakata, T.; Yoshida, Y.; Uruga, T.; Iwasawa, Y. Simultaneous Improvements in Performance and Durability of an Octahedral PtNix/C Electrocatalyst for Next-Generation Fuel Cells by Continuous, Compressive, and Concave Pt Skin Layers. ACS Catal. 2017, 7, 4642-4654. [CrossRef]

108. Wang, H.; Yin, S.; Li, Y.; Yu, H.; Li, C.; Deng, K.; Xu, Y.; Li, X.; Xue, H.; Wang, L. One-step fabrication of tri-metallic PdCuAu nanothorn assemblies as an efficient catalyst for oxygen reduction reaction. J. Mater. Chem. A 2018, 6, 3642-3648. [CrossRef]

109. Rivera Gavidia, L.M.; García, G.; Anaya, D.; Querejeta, A.; Alcaide, F.; Pastor, E. Carbon-Supported Pt-Free Catalysts with High Specificity and Activity toward the Oxygen Reduction Reaction in Acidic Medium. Appl. Catal. B 2016, 184, 12-19. [CrossRef]

110. Wang, X.; Orikasa, Y.; Takesue, Y.; Inoue, H.; Nakamura, M.; Minato, T.; Hoshi, N.; Uchimoto, Y. Quantitating the Lattice Strain Dependence of Monolayer Pt Shell Activity toward Oxygen Reduction. J. Am. Chem. Soc. 2013, 135, 5938-5941. [CrossRef] [PubMed]

111. Xie, S.; Choi, S.-I.; Lu, N.; Roling, L.T.; Herron, J.A.; Zhang, L.; Park, J.; Wang, J.; Kim, M.J.; Xie, Z.; et al. Atomic Layer-by-Layer Deposition of Pt on Pd Nanocubes for Catalysts with Enhanced Activity and Durability toward Oxygen Reduction. Nano Lett. 2014, 14, 3570-3576. [CrossRef] [PubMed]

112. US DOE, Fuel Cell Technologies Program: Multi-Year Research, Development, and Demonstration Plan-Planned Program Activities for 2011-2020. Available online: https:/ / www.energy.gov/sites/prod/ files/2017/05/f34/fcto_myrdd_fuel_cells.pdf (accessed on 1 November 2018).

113. Chen, G.; Kuttiyiel, K.A.; Li, M.; Su, D.; Du, L.; Du, C.; Gao, Y.; Fei, W.; Yin, G.; Sasaki, K.; et al. Correlating the electrocatalytic stability of platinum monolayer catalysts with their structural evolution in the oxygen reduction reaction. J. Mater. Chem. A 2018, 6, 20725-20736. [CrossRef]

114. Humbert, M.P.; Smith, B.H.; Wang, Q.; Ehrlich, S.N.; Shao, M. Synthesis and Characterization of Palladium-Platinum Core-Shell Electrocatalysts for Oxygen Reduction. Electrocatalysis 2012, 3, $298-303$. [CrossRef]

115. Bliznakov, S.T.; Vukmirovic, M.B.; Yang, L.; Sutter, E.A.; Adzic, R.R. Pt Monolayer on Electrodeposited Pd Nanostructures: Advanced Cathode Catalysts for PEM Fuel Cells. J. Electrochem. Soc. 2012, 159, F501-F506. [CrossRef]

116. Xu, Q.; Chen, W.; Yan, Y.; Wu, Z.; Jiang, Y.; Li, J.; Bian, T.; Zhang, H.; Wu, J.; Yang, D. Multimetallic AuPd@Pd@Pt core-interlayer-shell icosahedral electrocatalysts for highly efficient oxygen reduction reaction. Sci. Bull. 2018, 63, 494-501. [CrossRef]

117. He, D.S.; He, D.P.; Wang, J.; Lin, X.; Yin, P.Q.; Hong, X.; Wu, Y.E.; Li, Y.D. Ultrathin Icosahedral Pt-Enriched Nanocage with Excellent Oxygen Reduction Reaction Activity. J. Am. Chem. Soc. 2016, 138, 1494-1497. [CrossRef] [PubMed]

118. Wang, X.; Vara, M.; Luo, M.; Huang, H.; Ruditskiy, A.; Park, J.; Bao, S.; Liu, J.; Howe, J.; Chi, M.; et al. Pd@Pt Core-Shell Concave Decahedra: A Class of Catalysts for the Oxygen Reduction Reaction with Enhanced Activity and Durability. J. Am. Chem. Soc. 2015, 137, 15036-15042. [CrossRef] [PubMed]

119. Xiong, Y.; Yang, Y.; DiSalvo, F.J.; Abruña, H.D. Pt-Decorated Composition-Tunable Pd-Fe@Pd/C Core-Shell Nanoparticles with Enhanced Electrocatalytic Activity toward the Oxygen Reduction Reaction. J. Am. Chem. Soc. 2018, 140, 7248-7255. [CrossRef] [PubMed]

120. Kuttiyiel, K.A.; Sasaki, K.; Su, D.; Vukmirovic, M.B.; Marinkovic, N.S.; Adzic, R.R. Pt Monolayer on Au-Stabilized PdNi Core-Shell Nanoparticles for Oxygen Reduction Reaction. Electrochim. Acta 2013, 110, 267-272. [CrossRef]

121. Huang, J.-F.; Tseng, P.-K. High performance layer-by-layer $\mathrm{Pt}_{3} \mathrm{Ni}(\mathrm{Pt}$-skin)-modified Pd/C for the oxygen reduction reaction. Chem. Sci. 2018, 9, 6134-6142. [CrossRef] [PubMed]

122. Marković, N.M.; Ross, P.N., Jr. Surface science studies of model fuel cell electrocatalysts. Surf. Sci. Rep. 2002, 45, 117-229. [CrossRef] 
123. Shao, M.H.; Huang, T.; Liu, P.; Zhang, J.; Sasaki, K.; Vukmirovic, M.B.; Adzic, R.R. Palladium Monolayer and Palladium Alloy Electrocatalysts for Oxygen Reduction. Langmuir 2006, 22, 10409-10415. [CrossRef] [PubMed]

124. Chen, C.; Kang, Y.J.; Huo, Z.Y.; Zhu, Z.W.; Huang, W.Y.; Xin, H.L.L.; Snyder, J.D.; Li, D.G.; Herron, J.A.; Mavrikakis, M.; et al. Highly Crystalline Multimetallic Nanoframes with Three-Dimensional Electrocatalytic Surfaces. Science 2014, 343, 1339-1343. [CrossRef] [PubMed]

125. Huang, X.Q.; Zhao, Z.P.; Cao, L.; Chen, Y.; Zhu, E.B.; Lin, Z.Y.; Li, M.F.; Yan, A.M.; Zettl, A.; Wang, Y.M.; et al. High-performance transition metal-doped $\mathrm{Pt}_{3} \mathrm{Ni}$ octahedra for oxygen reduction reaction. Science 2015, 348, 1230-1234. [CrossRef] [PubMed]

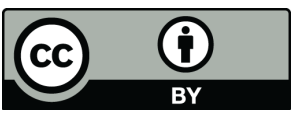

(C) 2019 by the authors. Licensee MDPI, Basel, Switzerland. This article is an open access article distributed under the terms and conditions of the Creative Commons Attribution (CC BY) license (http:/ / creativecommons.org/licenses/by/4.0/). 